\title{
O SUDSKOM TROŠKOVNOM NAGODBENOM PRAVU
}

Prof. emer. dr. sc. Mihajlo Dika*

UDK: 347.925:347.921.6(497.5)

DOI: 10.3935/zpfz.70.1.01

Izvorni znanstveni rad

Primljeno: ožujak 2020.

Odredba hrvatskog Zakona o parničnom postupku (ZPP) prema kojoj svaka stranka snosi svoje troškove ako je parnica završila sudskom nagodbom u kojoj glede toga nije drukčije ugovoreno (čl. 159. st. 1. ZPP-a), odnosno odredba prema kojoj troškovi tzv. izvanparnične (pretorske, preventivne) nagodbe koja je pokušana (čl. 324. ZPP-a), ali nije uspjela ulaze u parnične troškove (čl. 159. st. 2. ZPP-a) nisu novelom ZPP-a iz 2019. pretrpjele nikakve izmjene. Nije izmijenjena ni odredba čl. 324. st. 4. ZPP-a prema kojoj troškove postupka radi zaključenja izvanparnične sudske nagodbe podmiruje podnositelj prijedloga za pokretanje tog postupka. Novelom ZPP-a iz 2019. tek se posredno interveniralo u uređenje sudskog nagodbenog troškovnog prava unošenjem u ZPP posebne odredbe o sankcioniranju stranke koja ne postupi u skladu s uputom suda da sudjeluje u pokušaju mirnog rješenja spora, u kojemu se može zaključiti i sudska nagodba (čl. 186.d). U radu se nastoji sustavno - u povijesno-komparativnoj perspektivi - prezentirati i analizirati institut sudskog nagodbenog troškovnog prava. Težište je pri tome postavljeno na uređenje naknade troškova sudske nagodbe zaključene u parničnom postupku. Posebno je, međutim, obrađena i problematika troškova postupka za zaključenje tzv. izvanparnične sudske nagodbe, ali i ona koja se tiče izvansudske nagodbe o predmetu spora, troškova umješača u slučaju zaključenja sudske nagodbe te gubitka prava na naknadu daljnjih troškova prvostupanjskog postupka zbog nepostupanja po uputi suda za pokretanje postupka mirenja. Zaključno se konstatira da je sadašnjim uredenjem nepotpuno normiran institut o kojemu je riječ te da ono ostavlja otvorenim čitav niz vrlo ozbiljnih pitanja, zbog čega je moguće njihovo različito razumijevanje i rješavanje. Zato se i naglašava važnost potrebe da stranke prigodom definiranja sadržaja sudske - parnične ili izvanparnične - nagodbe uznastoje riješiti i ključna

* Dr. sc. Mihajlo Dika, professor emeritus Pravnog fakulteta Sveučilišta u Zagrebu, Trg Republike Hrvatske 3, Zagreb; mihajlo.dika@pravo.hr;

ORCID ID: orcid.org/0000-0002-5659-3779 
pitanja u vezi s naknadom troškova postupka u kojemu su je zaključile, posebno u slučajevima zaključenja međunagodbe ili djelomične nagodbe. Naglašava se i važnost monitorno-facilitacijske uloge suda u upozoravanju stranaka na naznačena pitanja i na pravne posljedice njihova nerješavanja.

Ključne riječi: nagodba; sudski troškovi; građanski postupak

\section{UVOD}

Sudsku nagodbu' stranke mogu zaključiti tijekom parničnog postupka (321. - 323. ZPP-a) $)^{2,3}$, ali i u posebnom izvanparničnom postupku koji može biti pokrenut prije ili paralelno s parničnim postupkom (324.). Sudsku nagodbu stranke mogu zaključiti i u postupku mirenja koji se provodi pred sucem izmiriteljem (186.d/7.; vidi infra ad VI.). ${ }^{4}$

Posebne odredbe o troškovima parničnog postupka u kojemu je zaključena sudska nagodba, odnosno postupka za zaključenje tzv. izvanparnične sudske nagodbe sadržane su u članku 159. i članku 324. ZPP-a. Prema odredbi stavka

1 O institutu sudske nagodbe usporedi Triva, S.; Dika, M., Građansko parnično procesno pravo, 7. izd., Zagreb, 2004., § 128.; Dika, M., Građansko parnično pravo, Sudske odluke i sudska nagodba, IX. knjiga, Zagreb, 2013., §§ 98. - 117.

2 U ovom radu odredbe pojedinih zakona označavat će se navođenjem broja članka, stavka odvojenog kosom crtom od broja članka, te točke ili rečenice u istom stavku, odvojene točkom od broja članka ili stavka. Brojevi više stavaka ili točaka istoga članka ili stavka međusobno će biti razdvojeni zarezom. Crtica između brojeva dvaju članaka ili stavaka koristit će se radi označavanja da se sve odredbe između tih brojeva odnose na tekst ispred njih. Za označavanje pojedinih propisa rabit će se njihove kratice koje će biti definirane $\mathrm{u}$ tekstu. Jedino će se odredbe ZPP-a u zagradama navoditi bez naznake kratice toga zakona. Za označavanje judikature koristit će se kratice sudova koji su donijeli odluku na koju se referira: VS - Vrhovni sud Republike Hrvatske; VTS - Visoki trgovački sud Republike Hrvatske; ŽS - Županijski sud koji će biti dodatno individualiziran naznakom kratice registracijske pločice automobila. Odgovarajuće će vrijediti i za kratice sudova iz federalnih jedinica bivše države. Pojedini časopisi i zbirke sudske prakse označavat će se kraticama koje se uobičajeno koriste ili su se koristile u domaćoj literaturi.

3 Zakon o parničnom postupku, Narodne novine, br. 53/1991, 91/1992, 112/1999, 88/2001, 117/2003, 88/2005, 2/2007, 84/2008, 96/2008, 123/2008, 57/2011, 148/2011 - pročišćeni tekst, 25/2013, 89/2014 - Odluka Ustavnog suda Republike Hrvatske, 70/2019. Za označavanje uređenja prema ZPP-u nakon novele 2019. koristit će se kratice ZPP, ZPP 19 i Zakon, dok će se za označavanje uređenja prema tom Zakonu prije te novele rabiti kratica ZPP 13.

4 Vidi bilj. 85. 
1. članka 159. ZPP-a svaka stranka snosi ${ }^{5}$ svoje troškove ako je parnica završena sudskom nagodbom, a u nagodbi nije drukčije ugovoreno, dok prema odredbi stavka 2. toga članka troškovi nagodbe koja je pokušana (324.), ali nije uspjela ulaze u parnične troškove. ${ }^{6}$ Prema odredbi članka 324. stavka 4. ZPP-a troškove postupka za zaključenje tzv. izvanparnične sudske nagodbe podmiruje podnositelj prijedloga. Navedene odredbe ZPP-a nisu izmijenjene i dopunjene novelom toga Zakona iz 2019. ${ }^{7}$ Tom se novelom ipak posredno interveniralo u uređenje naknade troškova vezanih uz zaključenje ili pokušaj zaključenja sudske nagodbe u parničnom postupku unošenjem u Zakon posebne odredbe o sankcioniranju stranke koja ne postupi u skladu s uputom suda da sudjeluje u pokušaju mirnog rješenja spora, u kojemu se može zaključiti i sudska nagodba (186.d, vidi infra ad VI.).

Iako se supra citirana odredba članka 159. stavka 1. ZPP-a o naknadi troškova postupka završenog sudskom nagodbom izrijekom odnosi na nagodbu zaključenu u parničnom postupku (321. - 323.; vidi infra ad II.), ona se, arg. a cohaerentia, a completudine, treba na odgovarajući način odnositi i na tzv. izvanparničnu ("pretorsku", "preventivnu"9) nagodbu (324., vidi infra ad III.). S druge strane, premda se također supra navedena odredba članka 159. stavka 2. ZPP-a izrijekom tiče samo tzv. izvanparnične nagodbe, nju bi, također, arg. a cohaerentia, a minori

Zakonom o izmjenama i dopunama Zakona o parničnom postupku iz 2003. (Narodne novine, br. 117/2003; ZIDZPP 03) riječ “podmiruje” u odredbi stavka 1. članka 159. ZPP-a zamijenjena je riječju "snosi”.

6 Odredbe članka 148. Zakona o parničnom postupku iz 1956. (Službeni list FNRJ, br. 4/1957, 52/1961; Službeni list SFRJ 12/1965, 1/1971, 23/1972, 6/1974; ZPP 56) o naknadi troškova postupka okončanog sudskom nagodbom doslovno se sadržajno podudaraju s odgovarajućim odredbama ZPP-a 76, ipak uz razliku da se u odredbi stavka 2. članka 148. ZPP-a 56 upućivalo na odredbu članka 313. toga Zakona, dok se u odredbi stavka 2. članka 159. ZPP-a 76 upućuje na odredbu članka 324. toga Zakona, na odredbe koje se sadržajno također podudaraju.

7 Zakon o izmjenama i dopunama Zakona o parničnom postupku iz 2019. (Narodne novine, br. 70/2019). Za označavanje ovog Zakona dalje u tekstu koristit će se kratica Novela 2019.

8 O upotrebi naziva pretorska nagodba za označavanje tzv. izvanparnične nagodbe u austrijskoj doktrini usporedi Fasching, H. W., Zivilprozeßrecht, Lehrbuch des österreichischen Ziviliprozeßrechts, 2. izd., Wien, 1990., str. 677; Kodek, G. E., u Fasching, H. W., Kommentar zu den Zivilprozeßgesetzen, 3. Band, Wien, 2004., str. 1364; Rechberger, W. H.; Simotta, D.-A., Zivilprozessrecht, Erkenntnisverfahren, 9. izd., Wien, 2017., str. 11, 368.

9 Usporedi Betetto, N., u Ude, L.; Betetto, N.; Galič, A., Rijavec, V.; Wedam Lukić, D.; Zobec, J., Pravdni postopek, Zakon s komentarjem, 2. knjiga, Ljubljana, 2006., str. 49. 
ad maius, per analogiam, trebalo na odgovarajući način primijeniti i na nagodbu koja je pokušana, ali nije uspjela u parničnom postupku (vidi infra ad III.5.).

Značenje odredbe koja se dotiče pitanja snošenja i naknade parničnih troškova ima, kako je to već supra nagoviješteno, i odredba kojom se na specifičan način sankcionira nepostupanje stranaka po uputi suda da pokrenu postupak mirenja (186.d/9.), u kojemu bi mogle sklopiti i sudsku nagodbu. Prema toj odredbi stranka koja je upućena pokrenuti postupak mirenja, a ne pristupi sastanku radi pokušaja mirenja, gubi pravo tražiti naknadu daljnjih troškova postupka pred prvostupanjskim sudom (vidi infra ad VI.).

Razrađenije odredbe o troškovima postupka (postupaka) okončanog (okončanih) sudskom nagodbom nalazile su se u § 149. ZSPGP-a ${ }^{10,11}$, koji je glasio: Troškovi sklopljenog poravnanja smatraće se kao uzajamno prebijeni, ako u njemu nije što drugo uglavljeno. To isto vredi i za troškove u parnicama koje su poravnanjem svršene, ako njihova naknada nije već jednoj stranci dosuđena pravosnažnom odlukom, a o toj dosudi ne bi ništa u poravnanju bilo spomenuto.//Stranke mogu sporazumno poveriti sudu odmeravanje iznosa onih parničnih troškova, koje po sklopljenom poravnanju jedna stranka ima da naknadi drugoj. Protiv ove odluke suda nema mesta pravnom leku.//Troškovi bezuspješno pokušanog poravnanja smatraće se kao parnični troškovi. To vredi i za slučaj § 529. Paragraf 529. ZSPGP-a odnosio se na mogućnost pokušaja sklapanja tzv. izvanparnične nagodbe. $U$ tom smislu odredbe toga paragrafa funkcionalno odgovaraju odredbama članka 324. ZPP-a, iako se s njima sadržajno ne podudaraju u cijelosti (vidi infra ad III.).

\section{TROŠKOVI SUDSKE NAGODBE ZAKLJUČENE U PARNIČNOM POSTUPKU}

\section{Općenito}

Odredbom prema kojoj svaka stranka snosi svoje troškove ako je parnica završena sudskom nagodbom, a u nagodbi nije drukčije ugovoreno (159/1.), utvrđeno je osnovno pravilo o konačnom snošenju troškova parničnoga po-

10 ZSPGP: Zakon o sudskom postupku u građanskim parnicama (Građanski parnični postupnik) iz 1929.

$11 \S$ 149. ZSPGP-a se u tom pogledu sadržajno u bitnome podudarao s § 47. austrijskog ZPO-a (Gesetz vom 1. 8. 1985. RGBl 113 über bürgerliche Rechtsstreitigkeiten / Zivilprozeßordnung/), s kasnijim izmjenama i dopunama (öZPO). § 47. öZPO glasi: (1) Die Kosten eines abgeschlossenen Vergleiches sind, wenn nicht etwas anderes vereinbart wird, als gegenseitig aufgehoben anzusehen. Dasselbe gilt von den Kosten des durch Vergleich erledigten Rechtsstreites, soweit deren Ersatz nicht bereits einer der Parteien rechtskräftig auferlegt ist. (2) Bleiben Vergleichsverhandlungen erfolglos, so ist die Verpflichtung zum Ersatze der mit denselben verbundenen Kosten von der Entscheidung der Hauptsache abhängig. 
stupka okončanog sudskom nagodbom zaključenom u tom postupku (322/2.). ${ }^{12}$ Na troškove postupka tzv. izvanparnične (pretorske) nagodbe odnosi se, kako je to već supra ad I. rečeno, odredba stavka 2. članka 159. ZPP-a prema kojoj troškovi nagodbe koja je pokušana $(324 \text {. })^{13}$, ali nije uspjela, ulaze u parnične troškove (vidi infra ad III.).

Pravilo da svaka stranka snosi svoje troškove ako je parnica završena sudskom nagodbom u kojoj glede troškova nije drukčije ugovoreno, nameće se zapravo "po prirodi stvari”. Ako se u nagodbi kojom se parnica završava ništa ne kaže o naknadi troškova postupka, pogotovo ako ona sadržava standardnu klauzulu da su one njome definitivno riješile spor koji je bio predmet postupka u kojemu su je zaključile, treba uzeti da su se one time implicite sporazumjele da je sklapanjem takve nagodbe i to pitanje definitivno riješeno između njih na način da svaka od njih snosi svoje troškove. Osim toga, budući da stranke same prethodno snose (predujmljuju) svaka svoje troškove postupka (152.) ${ }^{14}$, pa ako se u aktu kojim sporazumno okončavaju parnicu drukčije ne riješi pitanje snošenja tih troškova, svaka će od njih konačno snositi svoje troškove - nakon zaključenja nagodbe nema više procesnih mogućnosti da se od protivnika traži njihova naknada (arg. ex 164.). ${ }^{15} \mathrm{U}$ tom bi se smislu moglo govoriti o impliciranoj neoborivoj predmnjevi da su stranke pristale na to da svaka od njih snosi svoje troškove ako nisu što drugo utanačile u svojoj nagodbi. ${ }^{16}$

12 Prema odredbama članka 322. ZPP-a sporazum stranaka o nagodbi unosi se u zapisnik (stavak 1.), a nagodba se smatra zaključenom kad stranke, nakon pročitanog zapisnika o nagodbi, potpišu zapisnik (stavak 2.).

13 Članak 324. ZPP-a glasi: “Osoba koja namjerava podići tužbu može preko nižeg suda prvog stupnja na čijem području protivna strana ima prebivalište pokušati da postigne nagodbu.//Sud kojemu je takav prijedlog upućen pozvat će protivnu stranu i upoznati je s prijedlogom o nagodbi.//Troškove tog postupka podmiruje podnosilac prijedloga.".

14 Članak 152. ZPP-a glasi: "Svaka stranka prethodno sama podmiruje troškove koje je uzrokovala svojim radnjama.”.

15 Prema odredbama članka 164. ZPP-a: o naknadi troškova odlučuje sud na određen zahtjev stranke, bez raspravljanja (stavak 1.); stranka je dužna u zahtjevu određeno navesti troškove za koje traži naknadu (stavak 2.); zahtjev za naknadu troškova stranka je dužna staviti najkasnije do završetka raspravljanja koje prethodi odlučivanju o troškovima, a ako je riječ o donošenju odluke bez prethodnog raspravljanja, stranka je dužna zahtjev za naknadu troškova staviti u prijedlogu o kojem sud treba da odluči (stavak 3.); o zahtjevu za naknadu troškova sud će odlučiti u presudi ili rješenju kojim se završava postupak pred tim sudom (stavak 4.).

16 Ta bi predmnjeva bila na snazi sve dok stranke odgovarajućim pravnim sredstvima ne bi dovele $\mathrm{u}$ pitanje njezinu egzistentnost, npr. dok je posebnom tužbom ne bi pobile zbog mana u volji. O pobijanju sudske nagodbe usporedi Dika, op. cit. u bilj. 1, §§ 116. i 117. 
Mogućnost da stranke u svojoj nagodbi - izrijekom ili prešutno - riješe i pitanje naknade troškova postupka izraz je dispozitivnog karaktera toga instituta (3/3., 321/1., 4.), autonomije volje stranaka u parničnom postupku.

Budući da glede toga nema nikakvih ograničenja u odredbi članka 159. stavka 1. ZPP-a, ona bi se odnosila i na troškove učinjene tijekom i na one učinjene u povodu postupka u kojemu je nagodba zaključena (15l/1. $)^{17}$, uključujući i troškove u vezi s njezinim zaključenjem. ${ }^{18}$

Pravilo da svaka stranka snosi svoje troškove ako je parnica završena sudskom nagodbom znači da će svaka od njih snositi već plaćene i da će biti dužna platiti još neplaćene pristojbe u vezi s radnjama koje je poduzela tijekom postupka, da će sama snositi sve troškove svojeg možebitnog zastupanja, troškove osobnoga dolaženja na sud, materijalne troškove pripremanja podnesaka i priloga, troškove koje je predujmila radi poduzimanja drugih procesnih radnji, npr. radi izvođenja dokaza (152., 153.) itd. - zapravo sve izdatke učinjene u tijeku ili u povodu postupka u kojemu je zaključena nagodba (arg. ex 151/1.). ${ }^{19}$

Prema supra ad I. citiranoj odredbi § 49. stavka 1. reč. 2. ZSPGP-a smatralo se da predmnjeva o uzajamnoj prebijenosti troškova sklopljene nagodbe "vredi i za troškove u parnicama koje su poravnanjem svršene, ako njihova naknada nije već jednoj stranci dosuđena pravosnažnom odlukom, a o toj dosudi ne bi ništa u poravnanju bilo spomenuto". U austrijskoj je doktrini sadržajno podudarna odredba § 147. stavka 1. reč. 2. öZPO-a, shvaćena i u smislu da se predmnjeva sadržana u toj odredbi odnosi i na troškove "provizornog postupka"20, dakle i na troškove postupaka za određivanje privremenih mjera osiguranja.

O tome djeluje li i kako sudska nagodba na odluke o naknadi troškova postupka koje su donesene tijekom postupka prije njezina zaključenja, vidi infra ad II.8.

Strankama je prepušteno (u granicama dopuštenih dispozicija - 3/3., 321/4.) ) $^{21}$ da slobodno urede pitanje naknade troškova postupka u kojemu je zaključena

17 Vidi infra.

18 Tako s aspekta slovenskog ZPP-a iz 1999., odredbe čijeg su se članka 159. sadržajno podudarale s odredbama članka 159. hrvatskog ZPP-a, Betetto, op. cit. u bilj. 9, str. 49.

19 Prema odredbi članka 151. stavka 1. ZPP-a parnične troškove čine izdaci učinjeni u tijeku i u povodu postupka.

20 Usporedi Bydlinski, M., u Fasching, H. W., Kommentar zu dem Zivilprozeßgesetzen, 2. Band/1. Teilband, Wien, 2002., str. 698.

21 Prema odredbi članka 3. stavka 3. ZPP-a sud neće uvažiti raspolaganja stranaka koja su u suprotnosti s prisilnim propisima i pravilima javnog morala, dok se prema odredbi članka 321. stavka 4. ZPP-a pred sudom ne može zaključiti nagodba u pogledu zahtjeva kojima stranke ne mogu raspolagati (3/3.). 
sudska nagodba. One mogu troškove u cijelosti ili djelomično prevaliti na jednu od stranaka i, ako žele da se već na temelju nagodbe može izravno tražiti ovrha, stipulirati dužnost te stranke da njihov iznos utvrđen u nagodbi naknadi protivnoj stranci (arg. ex 27. OZ-a). ${ }^{22}$ Pritom stranke ne mogu svojim sporazumom utjecati na obveze neke od njih prema trećima, uključujući i na obveze prema državi za plaćanje sudskih pristojbi ili za naknadu troškova sudu, npr. u vezi s izlaskom sudskog povjerenstva izvan sudske zgrade radi obavljanja uviđaja. Stranka koja je bila u obvezi prema trećima ostaje i dalje u toj obvezi, npr. u obvezi da svjedoku ili vještaku naknadi određene troškove. Stranke jedino mogu predvidjeti da će obvezu jedne od njih namiriti druga. Takav bi njihov sporazum, u ovisnosti o sadržaju konkretnih stipulacija u nagodbi, mogao imati i značenje ugovora u korist trećega s elementima sporazuma o pristupanju dugu.

Premda se u odredbi stavka 1. članka 159. ZPP-a izrijekom govori o parnici završenoj sudskom nagodbom, zbog čega bi se moglo uzeti da se ta odredba neposredno odnosi samo na nagodbu zaključenu u parničnom postupku, trebalo bi, kako je to već rečeno supra ad I., uzeti da se ona na odgovarajući način odnosi i na tzv. izvanparničnu nagodbu (324., vidi infra ad IV.).

O utjecaju izvanparnične nagodbe kojom je riješen i spor koji je bio predmet nekog parničnog postupka na pravo na naknadu troškova i toga postupka vidi infra ad (II.7. i) III.4.

\section{Naknadno postavljanje zahtjeva za naknadu troškova postupka}

Zahtjev za naknadu troškova postupka u slučaju zaključenja sudske nagodbe na pripremnom ročištu ili na ročištu za glavnu raspravu, kad bi takva mogućnost bila predviđena nagodbom, stranke bi bile dužne postaviti na ročištu na kojemu bi ona bila zaključena (arg. ex 164/3. $)^{23,24}$.

Zahtjev za naknadu troškova postupka koji bi stranke podnijele u postupku u kojemu su zaključile sudsku nagodbu nakon što bi tu nagodbu zaključile treba odbaciti. ${ }^{25}$ Valja, naime, uzeti da je zaključenjem sudske nagodbe, kojom

22 OZ: Ovršni zakon (Narodne novine, br. 112/2012, 25/2013, 93/2014, 55/2016 odluka USRH, 73/2017). Prema odredbi članka 27. OZ-a sudska nagodba ovršna je ako je tražbina koju prema njoj treba ispuniti dospjela.

O odredbi članka 164. stavka 3. ZPP-a vidi bilj. 15.

24 Tako na temelju sadržajno podudarnih odredaba slovenskog ZPP-a iz 1999. Betetto, op. cit. u bilj. 9, str. 49.

25 U postjugoslavenskoj doktrini, utemeljenoj na ZPP-u 76 (Poznić, B., Komentar Zakona o parničnom postupku "prema tekstu Zakona iz 1976. s docnijim izmjenama i dopunama", 
glede troškova postupka nije ništa drugo određeno, spor snagom rei iudicialiter transactae okončan ne samo u pogledu glavne stvari na koju se ona odnosi, već i u pogledu prava na naknadu troškova toga postupka - jednako kao da je nagodbom utvrđeno da će svaka stranka snositi svoje troškove postupka koji je prethodio njezinu zaključenju (arg. ex 323.). ${ }^{26}$ Zahtjev za naknadu troškova postupka u slučaju o kojemu je riječ imao bi značenje specifične "tužbe" kojom bi bio pokrenut nastavni incidentalni postupak za odlučivanje o zahtjevu o kojemu je predmnijevano implicite zaključena sudska nagodba. ${ }^{27}$

\section{Sporazum stranaka kojim ovlašćuju sud da u povodu sudske nagodbe odluči o troškovima postupka}

Prema citiranoj odredbi § 149. stavka 2. reč. 1. ZSPGP-a (vidi supra ad I.) stranke su mogle sporazumno povjeriti sudu odmjeravanje iznosa onih parničnih troškova koje je po sklopljenoj nagodbi ("sklopljenom poravnanju”) jedna stranka imala naknaditi drugoj, s time da prema odredbi § 149. stavka 2. reč. 2. ZSPGP-a protiv "ove odluke suda" nije bio dopušten pravni lijek.

U ZPP-u nema odgovarajuće odredbe.

U relativno starijoj judikaturi, utemeljenoj na ZPP-u 5628, koji više nije sadržavao odredbu koja bi odgovarala onoj iz § 149. stavka 1. reč. 1. ZSPGP-a, ali čija se odredba članka 148. stavka 1. sadržajno podudarala s važećom odredbom članka 159. stavka 1. ZPP-a 76, bilo je zauzeto stajalište da se stranka nagodbom može obvezati da protivniku plati parnične troškove na temelju sudske odluke, pri čemu je takva stipulacija shvaćena u smislu da će sud biti dužan naknadno,

Beograd, 2009., str. 344), pozivanjem na relativno stariju judikaturu (Okr. Sud u Kraguj., Gž-246/77, od 24. 3. 1977., Bilt. VSSrb, br. 5/1977, str. 21) iznosi se stajalište po kojemu treba odbiti zahtjev kojim stranka traži da se odluči o troškovima postupka nakon potpisivanja zapisnika o nagodbi kojim nije odlučeno o troškovima postupka.

26 Prema odredbi članka 323. ZPP-a sud je dužan tijekom cijelog postupka po službenoj dužnosti paziti vodi li se parnica o predmetu o kojemu je ranije bila zaključena sudska nagodba i, ako utvrdi da se takva parnica vodi, dužan je odbaciti tužbu.

27 Učinci predmnjeve da u slučaju u kojemu su stranke zaključile sudsku nagodbu kojom nešto drugo nije ugovoreno svaka stranka snosi svoje troškove nastupaju ex lege. Ta bi predmnjeva, zapravo, činila zakonom propisani podredni sadržaj te nagodbe. Stajalište da učinci uzajamnog prijeboja troškova postupka u slučaju zaključenja sudske nagodbe u kojoj nešto drugo nije uglavljeno nastupaju ex lege zastupa se i s aspekta austrijskog prava, usporedi Bydlinski, op. cit. u bilj. 20, str. 699.

28 ZPP 56: Zakon o parničnom postupku iz 1956. (Službeni list FNRJ, br. 4/1957, 52/1961, Službeni list SFRJ, br. 12/1965, 1/1971, 23/1972, 6/1974). 
nakon zaključenja nagodbe, donijeti rješenje o naknadi troškova. Prema odluci o kojoj je riječ, ako stranke nisu pri tome odredile neko ograničenje osnove za sudsko odmjeravanje troškova, kao osnovu je trebalo uzeti iznos za koji je tekla parnica, a ne iznos nagodbe. Zauzeto je, pritom, za razliku od odredbe § 149. stavka 2. reč. 2. ZSPGP-a, stajalište da se rješenje o tako odmjerenim troškovima može pobijati žalbom. ${ }^{29} \mathrm{U}$ doktrini je s obzirom na uređenje prema ZPP-u 76 ocijenjeno da je izloženo stajalište svrhovito jer doprinosi mirnom rješenju spora - zato što pokušaj zaključenja sudske nagodbe ponekad ne uspijeva zbog neslaganja stranaka o iznosu naknade koju bi jedna od njih trebala platiti drugoj. ${ }^{30}$

O tome može li se za navedeno stajalište zauzeto u judikaturi utemeljenoj na ZPP-u 56 naći uporište i u zakonskom uređenju instituta prema ZPP-u 56 i ZPP-u 76 u literaturi su izražena oprečna stajališta. Prema jednom od njih, utemeljenom na ZPP-u 76, takvog uporišta ne bi bilo ${ }^{31}$, po drugome, utemeljenom na ZPP-u 56, koji se u pogledu normativne osnove za zauzimanje stajališta o iznesenom problemu nije razlikovao od ZPP-a 76 (vidi supra), mogućnost takve dispozicije u nagodbi bila bi u skladu s važećim uređenjem. ${ }^{32}$

29 VS SLO, P̌̌-496, od 3. 7. 1969., Poreč 1969/2, str. 29. - cit. prema Poznić, op. cit. u bilj. 25 , str. 345 .

Ibid.

31 Ibid.

32 Bazala, B., Parnični troškovi po Zakonu o parničnom postupku, Jugoslavenska advokatura, br. 1, 1958., str. 34 i 35, koji se pritom pozivao i na odredbu stavka 2. § 149. ZSPGP-a iz 1929., koja je izrijekom predviđala da stranke mogu sporazumno povjeriti sudu odmjeravanje iznosa onih parničnih troškova "koje po sklopljenom poravnanju jedna stranka ima da naknadi drugoj", ističući da se ipak ne bi "moglo uzeti da je to nemogućno i da to ne bi bilo u skladu s osnovnom odredbom o naknadi parničnih troškova kod zaključenja nagodbe”, namećući toj mogućnosti određena ograničenja. Naime, prema ovom autoru, stranke "sigurno ne će moći ugovoriti u nagodbi da će sud odlučiti o naknadi parničnih troškova i ako bi to stranke ugovorile, tada kao da nisu u pogledu naknade troškova uopće ništa drugačije ugovorile i svaka bi stranka snosila svoje troškove. Ali stranke će ipak moći ugovoriti u nagodbi da sud ima odmjeriti samo visinu onih troškova za koje su stranke u nagodbi ugovorile da ih ima jedna stranka naknaditi drugoj u cijelosti ili u određenom dijelu.". Prema njegovu bi mišljenju, za razliku od odredbe § 149. ZSPGP-a, koja je propisivala da protiv takve odluke suda nema pravnog lijeka, "kako u novom parničnom postupku nije u pogledu mogućnosti tog odmjeravanja visine troškova ništa određeno, nije moglo biti ništa određeno ni u pogledu žalbe protiv tog rješenja. Uslijed toga bi protiv takvog rješenja bila dopuštena i žalba, jer nije određeno da žalba nije dopuštena (čl. 364/1.).”. 
U slovenskoj doktrini zauzeto je stajalište da bi sud u navedenom slučaju morao vrednovati uspjeh stranaka uspoređujući zahtijevani i dogovoreni iznos. ${ }^{33}$

Prema austrijskoj judikaturi stranke bi u slučaju u kojemu bi spor u glavnoj stvari riješile nagodbom bile ovlaštene prepustiti sudu da riješi naknadu troškova postupka, uzimajući pritom u obzir hipotetski ishod parnice, dakle, ispitujući u kojoj je mjeri koja od stranaka dala povod za nju, pri čemu sadržaj nagodbe ne bi predstavljao nikakvu supstancu koju bi trebalo vrednovati prigodom donošenja odluke o troškovima. ${ }^{34}$

Treba uzeti da bi i de lege lata stranke mogle svojom nagodbom ovlastiti (obvezati) sud da o troškovima postupka odluči neovisno o tome što je o glavnoj stvari sklopljena sudska nagodba. Naime, sklapanjem sudske nagodbe o glavnoj stvari i unoseći u tu nagodbu stipulaciju kojom bi ovlašćivale (obvezivale) sud da odluči o troškovima postupka koji bi obuhvaćali troškove postupka koji je prethodio njezinu zaključenju, troškove njezina zaključenja te, eventualno, i troškove koji bi naknadno mogli biti određeni (npr. troškove koje treba naknaditi sudu, svjedocima, vještacima itd., infra ad II.4.), stranke bi zapravo spor reducirale na spor o troškovima postupka - predmet spora bi nakon sklapanja takve nagodbe bili zahtjevi stranaka za naknadu troškova postupka, analogno kao u slučaju u kojemu se tužbeni zahtjev svodi na zahtjev za naknadu troškova postupka. U prilog navedene mogućnosti govorila bi i okolnost da stranke mogu u nagodbi utanačiti da će pitanje troškova postupka naknadno pokušati sporazumno riješiti te da će, ako u tome ne uspiju, od suda zatražiti da ga riješi prema određenim kriterijima. U razmatranom slučaju bi zapravo nagodba bila

33 Betetto op. cit. u bilj. 9, str. 49, pozivajući se na rješenje Vrhovnog suda Slovenije (VSL) br. II Cp 340/2004 od 14. 4. 2004., u kojemu je sud zauzeo stajalište da je zbog zaključenja sudske nagodbe prigodom "sudskog odmjeravanja" parničnih troškova isključen pristup odvojenog vrednovanja uspjeha po osnovi i visini jer ono pretpostavlja egzaktno utvrđivanje dijela uspjeha po osnovi i visini.

34 Usporedi Bydlinski, op. cit. u bilj. 20, str. 699, koji u vezi s ovom praksom ističe da je najviši sud $(\mathrm{OGH})$ zauzeo stajalište da bi u takvim slučajevima radi utvrđenja premisa za donošenje odluke bilo primjereno pojednostavljenje analognom primjenom odredbe § 50. stavka 2. öZPO, što znači da bi sud svoju odluku mogao donijeti po slobodnoj ocjeni ako bi to utvrđivanje zahtijevalo nerazmjerne troškove ( $\$ 273$. öZPO-a; 223/1. ZPP-a). Pravilnost ovog stajališta dovedena je u pitanje osobito stoga što u praksi nije bilo sporno da se u usporedivom slučaju tužbeni zahtjev može ograničiti na zahtjev za naknadu troškova, odnosno da se u slučaju u kojemu bi tuženik koji nije dao povod za tužbu priznao tužbeni zahtjev prigodom prve prigode za to i koji bi u tom slučaju imao pravo na naknadu troškova (§ 45. öZPO-a; članak 157. ZPP-a) relevantne činjenice utvrđuju po općim pravilima; usporedi Bydlinski, op. cit. u bilj. 20 , str. 700 . 
postignuta u glavnoj stvari (djelomična nagodba), dok bi o troškovima postupka sud trebao donijeti naknadnu odluku. Pritom bi izričit sporazum stranaka o tome bio potreban radi toga da bi se otklonila primjena implicirane predmnjeve da su se stranke zaključenjem sudske nagodbe kojom izrijekom nisu riješile i pitanje troškova postupka sporazumjele da svaka snosi svoje troškove.

O sadržaju sporazuma kojim bi stranke "povjerile" sudu da donese odluku o troškovima postupka u kojemu su zaključile nagodbu ovisilo bi i bi li sud kao osnovu za svoju odluku trebao uzeti zaključenu sudsku nagodbu kao "medij” kojim je riješen spor ili bi kao osnovu trebao uzeti spor koji je bio pokrenut tužbom kao da do sklapanja nagodbe nije došlo. U prvom slučaju sud bi o troškovima postupka odlučio uzimajući u obzir ono što je bilo traženo tijekom postupka prije sklapanja nagodbe i nagodbu kojom su stranke riješile svoj spor koji je glede toga postojao između njih, pri čemu bi ono što je postignuto nagodbom bilo vrednovano kao da je strankama dosuđeno odlukom suda - uspjeh stranaka u parnici vrednovao bi se prema sadržaju nagodbe. U drugom slučaju sud bi zapravo morao prejudicijelno riješiti spor među strankama neovisno o zaključenoj nagodbi da bi ocijenio u kojoj bi mjeri svaka od njih uspjela u sporu da nije došlo do njezina zaključenja. ${ }^{35}$

Ako bi stranke svojim utanačenjem u nagodbi odredile kriterije za donošenje sudske odluke o troškovima postupka, tada bi u načelu trebalo slijediti te kriterije. U slučaju dvojbe trebalo bi se opredijeliti za prvu soluciju, pri čemu bi se polazilo od realiteta da stranke sadržajem postignute nagodbe određuju i sadržaj meritornog okončanja spora s analognim učincima kao da je spor riješen meritornom odlukom suda. Osim toga, ta bi solucija bitno olakšavala položaj suda prigodom utvrđivanja premisa za donošenje odluke o troškovima - za to bi bilo dovoljno uzeti u obzir ono što je traženo u glavnoj stvari tijekom postupka i ono što je postignuto nagodbom. Prema drugoj navedenoj soluciji sud bi, kako je to već rečeno, morao prejudicijelno meritorno riješiti spor o glavnoj stvari kao da nagodba nije zaključena, provesti postupak kao da do nje nije došlo, eventualno izvoditi i dokazivanje, i onda na temelju rezultata takvog prejudicijelnog suđenja donijeti odluku o troškovima. Upravo bi zbog toga, zapravo, trebalo optirati za stajalište da sporazum koji bi predviđao ovu soluciju ne bi bio dopušten, među ostalim i zato što bi se njime od suda tražilo da o troškovima postupka odlučuje neovisno o ishodu spora glede glavne stvari, da o jednom sporednom zahtjevu odluka o kojemu je sadržajno uvjetovana odlukom o glavnoj stvari, odlučuje na temelju kriterija koje su stranke utanačile, a ne na temelju, u osnovi, kogentnih

35 U prilog ove druge mogućnosti opredijelio se VS SLO u judikatu cit. u bilj. 29, ali i Bazala, op. et loc. cit. u bilj. 32. O tome da je takav pristup prihvaćen i u austrijskoj sudskoj praksi usporedi Bydlinski, op. cit. u bilj. 20, str. 700; vidi i bilj. 29. 
normi troškovnog materijalnog prava (3/3., 321/4.). ${ }^{36}$ Zaključenjem nagodbe stranke bi preuzimale i rizik da se pitanje troškova postupka koje nisu riješile nagodbom riješi odlukom suda u skladu s njome. U prilog ovom stajalištu govorili bi i pragmatični razlozi - njime bi se, kako je to već supra rečeno, sud oslobodio potrebe da, unatoč tome što je sudbina glavne stvari riješena nagodbom, provodi postupak radi prejudicijelnog rješenja pitanja kako bi riješio spor da do nje nije došlo, i to samo radi toga da bi riješio pitanje troškova postupka. Od stranaka bi trebalo moći očekivati da kad nagodbom rješavaju glavnu stvar, na isti način riješe i pitanje troškova postupka, odnosno da sudu, eventualno, prepuste da o troškovima odluči u skladu s onim kako je njome riješen spor o glavnoj stvari. U prilog ovog stajališta išla bi, arg. a contrario, i okolnost da u ZPP-u 56 i ZPP-u 76 nema više odredbe koja bi odgovarala odredbi § 149. stavku 2. reč. 1. ZSPGP-a (vidi supra ad I.), zbog čega se de lege lata ne bi na nju moglo pozivati kao na odredbu iz koje bi se izvodilo drugo navedeno stajalište. ${ }^{37}$

U relativno recentnijoj hrvatskoj judikaturi zauzeto je stajalište da bi stranke bile ovlaštene u svojoj nagodbi odrediti da će odluku o parničnim troškovima donijeti sud "posebnim rješenjem prema troškovnicima koje predaju u spis", da se iz okolnosti da se stranke nisu sporazumjele o tome da će jedna drugoj platiti određeni iznos na ime naknade parničnih troškova, ili da će svaka stranka snositi svoje parnične troškove ne može izvesti da se stranke "nisu suglasile u vezi pitanja naknade parničnih troškova u ovom sporu" - one su se "sporazumjele da o parničnim troškovima odluči sud". ${ }^{38}$ Pritom je Vrhovni sud, uzevši "u ob-

36 Norme troškovnog materijalnog prava, premda u određenim aspektima imaju naglašeniju dispozitivnu dimenziju, u osnovi su javnopravnog karaktera i stranke u načelu ne bi mogle odrediti kriterije po kojima bi se odlučivalo o zahtjevima za naknadu troškova postupka - te bi norme u tom smislu bile nekonvencionalne naravi, kao što su to u načelu općenito uzevši norme koje uređuju odnose koji se zasnivaju u sudskim postupcima.

37 Situacija u kojoj bi spor bio riješen nagodbom kojom bi stranke "zadužile" sud da o troškovima postupka naknadno odluči razlikuje se od situacije u kojoj je tužba glede glavne stvari povučena i spor reduciran na zahtjev o troškovima postupka. U prvoj situaciji spor je glede glavne stvari meritorno riješen nagodbom, a u drugoj nema meritorne odluke o glavnoj stvari.

38 Rješenje Vrhovnog suda Republike Hrvatske br. Rev-12/05 od 24. 11. 2015. Cit. prema Kaladić, I., Sporna primjena odredbe članka 159. stavka I. Zakona o parničnom postupku, Pravo i porezi, br. 10, 2007., str. 18 i 19. U ovoj su pravnoj stvari prvostupanjski i drugostupanjski sud bili zauzeli stajalište da stranke - time što su u nagodbi suglasno predložile da odluku o parničnim troškovima donese sud posebnim rješenjem prema troškovnicima koje će predati u spis - zapravo nisu drukčije ugovorile snošenje parničnih troškova, zbog čega su odlučili da svaka stranka snosi svoje troškove. 
zir istaknute tužbene i protutužbene zahtjeve o kojima je dijelom presuđeno" presudama prvostupanjskog i drugostupanjskog suda te okolnost da su stranke o "preostalom dijelu (...) sklopile sudsku nagodbu" utvrdio dijelove u kojima su pojedine od stranaka uspjele u sporu. Iako se Vrhovni sud nije izrijekom izjasnio o kriteriju od kojega je pošao prigodom utvrđivanja dijelova u kojima su pojedine od stranaka uspjele u sporu, treba uzeti, zato što je prigodom utvrđivanja tih dijelova vodio računa ne samo o dijelovima zahtjeva o kojima je odlučeno djelomičnom presudom, već i o zaključenoj nagodbi, da je kao jedan od relevantnih kriterija uzeo i uspjeh stranaka u sporu prema toj nagodbi. ${ }^{39}$

Blisko supra razmotrenom pitanju o sudbini parničnih troškova u slučaju sporazuma kojim stranke ovlašćuju sud da u povodu sudske nagodbe odluči o troškovima postupka jest i pitanje kako odlučiti o troškovima u slučaju u kojemu su stranke sudsku nagodbu izrijekom ograničile na glavnu stvar. U doktrini su ponuđena dva rješenja: prvo, da sud u takvom slučaju mora o naknadi parničnih troškova odlučiti tako da prethodno riješi pitanje osnovanosti tužbenog zahtjeva i, drugo, da kao osnovu svoje odluke uzme odredbu članka 159. stavka 1. ZPP-a. Argument za drugo navedeno rješenje, koje je ocijenjeno kao uvjerljivije, bio bi da je zahtjev za naknadu troškova akcesoran, ali ne u smislu da je "pripadak" glavnog zahtjeva (kao što su to kamate kod novčanih tražbina), već u odnosu prema parnici. ${ }^{40}$ Čini se prihvatljivijim drugo izloženo rješenje iz istih razloga iz kojih je odgovarajuće stajalište zauzeto u vezi s prethodno izloženim pitanjem sudbine parničnih troškova u slučaju u kojemu su stranke nagodbom prepustile sudu da o njima odluči.

39 Kaladić, op. cit. u bilj. 38, str. 19 i 20, interpretirajući odluku Vrhovnog suda u smislu da je taj sud zauzeo stajalište da bi u slučaju u kojemu su stranke svojom nagodbom odredile da će o troškovima postupka odlučiti sud, sud o troškovima postupka trebao odlučiti prema odredbi članka 154. stavka 2. ZPP-a, dakle prema postignutom uspjehu u parnici, ipak se izrijekom ne izjašnjava o tome po kojem bi kriteriju sud vrednovao uspjeh stranaka u parnici - polazeći od uspjeha koji bi se ocjenjivao prema onome što je traženo i onome što je postignuto nagodbom, ili prema uspjehu koji bi stranke postigle da do nje nije došlo.

Betetto, op. cit. u bilj. 9, str. 49, pozivajući se na obiter dicta Vrhovnog suda Slovenije u obrazloženju pravnog shvaćanja opće sjednice od 15. 12. 1998. - Pravna mnenja, 2/98, str. 4, ali citirajući i odluku Višeg suda u Subotici, Hž-732/79 od 25. 9. 1979. (Bilten Vrhovnog suda Vojvodine 3/80, str. 28), prema kojoj zahtjev kojim stranke, koje nagodbom o glavnoj stvari nisu postigle i sporazum o parničnim troškovima i izrijekom traže da o njima odluči sud, ima značenje glavnog zahtjeva o kojemu treba odlučiti presudom. 


\section{Naknada troškova sudu odnosno drugim sudionicima u postupku}

Zaključenjem sudske nagodbe ne prestaju obveze stranaka da trećim osobama i, eventualno, državi odnosno sudu nadoknade neke troškove. Sud, naime, može svjedocima, vještacima i tumačima naknadno, nakon zaključenja nagodbe, dosuditi neke troškove. Sud je pritom u pravilu dužan naložiti da pojedine od tih troškova tim osobama naknadi ona od stranaka koja ih je bila dužna prethodno snositi, a ako je glede toga postojala obveza obiju, objema naložiti da to učine - svakoj u jednoj polovici dijela (arg. ex 153/2.). ${ }^{41}$

Ako neka od stranaka ne podmiri ili ako obje ne podmire sudske troškove - npr. ako ne plate sudske pristojbe, ili sudu ne naknade troškove izvođenja dokaza sredstva za podmirenje kojih je sud predujmio iz vlastitih sredstava ili troškove suda u vezi s uviđajem obavljenim izvan sudske zgrade, te troškove, neovisno o sadržaju sudske nagodbe, u načelu treba snositi stranka koja ih je bila dužna predujmiti, odnosno obje stranke svaka u jednoj polovici dijela ako su obje to bile dužne učiniti (arg. ex 153/2., 153/4.). Stranke ne mogu, kako je to već supra ad II.3. rečeno, sudskom nagodbom izmijeniti pravo trećih osoba da od pojedinih od njih traže naknadu svojih troškova - one mogu utvrditi dužnost pojedine od njih da te troškove naknadi, u kojem slučaju takve stipulacije u nagodbi mogu, ovisno o svojem sadržaju, imati i učinke ugovora u korist trećeg, odnosno ugovora o pristupanju dugu. Sudska nagodba u tom pogledu ne može mijenjati sadržaj tih obveza prema državi, sudu ili trećim osobama. Stranke mogu, međutim, nagodbom utanačiti da će te troškove jedna od njih platiti umjesto druge, odnosno da će joj ih naknaditi. Ako obveza jedne od stranaka da odnosne troškove naknadi drugoj ne bude utvrđena na način na koji obveze trebaju biti utvrđene u ovršnoj ispravi, vjerovnik iz nagodbenog odnosa može svoja prava na njihovu naknadu ostvarivati po općim pravilima, dakle redovito podnošenjem tužbe.

41 Prema odredbama članka 153. stavka 2. ZPP-a kad izvođenje dokaza predlože obje stranke, ili kad ga sud odredi po službenoj dužnosti, sud će odrediti da iznos potreban za podmirenje troškova polože obje stranke na jednake dijelove, s time da u slučaju u kojemu je odredio izvođenje dokaza po službenoj dužnosti može odrediti da iznos položi samo jedna stranka, dok prema odredbi članka 153. stavka 4. ZPP-a ako sud izvede dokaz iako predujam za njegovo izvođenje nije položen, rješenjem će naložiti stranci da u roku od osam dana određenu svotu plati svjedoku ili vještaku, s time da žalba protiv toga rješenja ne odgađa ovrhu. 


\section{5. "Međunagodba" i "djelomična nagodba"}

\subsection{Općenito}

Prema odredbi članka 165. ZPP-a u međupresudi ili djelomičnoj presudi sud može izreći da se odluka o troškovima ostavlja za kasniju presudu, osim ako kod djelomične presude nije riječ o slučaju u kojemu se takvom presudom postupak završava za nekog od suparničara, u kojem je slučaju sud dužan odlučiti o zahtjevu za naknadu troškova stranaka između kojih se tom odlukom postupak pred njime završava (164/5.). Iz navedene odredbe članka 165. ZPP-a određeno proizlazi da je sud ovlašten, ali i da nije dužan prigodom donošenja međupresude i, uz navedenu iznimku, djelomične presude odlučiti i o troškovima postupka - treba uzeti u dijelu u kojemu bi se oni ticali onoga o čemu je odlučeno tim presudama.

U Zakonu nema posebnih odredaba o naknadi troškova u slučaju međunagodbe i djelomične nagodbe. Zato bi, u slučajevima u kojima bi bile zaključene takve nagodbe, trebalo na odgovarajući način uzeti u obzir kako opće odredbe o naknadi troškova postupka okončanog nagodbom (159.) tako i odredbe o odlučivanju o troškovima postupka u međupresudi ili djelomičnoj presudi (164/5., 165.).

\subsection{Medunagodba}

Ako je međupresuda presuda "o osnovi zahtjeva" koju sud može "iz razloga svrsishodnosti” donijeti u slučaju u kojemu je tužitelj osporio i osnovu i iznos tužbenog zahtjeva, a u pogledu osnove je stvar sazrela za donošenje odluke $(330 / 1 .)^{42}$, tada bi međunagodba bila nagodba kojom bi stranke riješile (samo) pitanje osnovanosti osnove tužbenog zahtjeva (arg. ex 321/2.). ${ }^{43}$

Stranke bi međunagodbom, analogno kao i sud međupresudom, bile ovlaštene riješiti i pitanje troškova postupka koji bi se odnosili na dionicu postupka u kojoj bi se rješavalo pitanje osnovanosti osnove tužbenog zahtjeva. Međutim, i u

42 O međupresudi usporedi Triva, Dika, op. cit. u bilj. 1, str. 594 - 597; Dika, op. cit. u bilj. 1, str. 115. i slj.

43 Prema odredbi članka 321. stavka 2. ZPP-a nagodba koju bi stranke zaključile u postupku pred parničnim sudom može se odnositi na cijeli tužbeni zahtjev ili na jedan njegov dio. Iz ove bi odredbe, koja izravno ima u vidu kvalitativno-kvantitativno određeni dio zahtjeva, trebalo izvesti i da bi se ona mogla odnositi i samo na "kvalitativno" određeni dio tužbenog zahtjeva, na njegovu osnovu. 
tome bi bila razlika između međupresude i međunagodbe, ako međunagodbom ne bi izrijekom bilo drukčije ugovoreno, osobito ako njome ne bi bilo određeno da se sudu prepušta da pitanje troškova postupka naknadno riješi ${ }^{44}$, trebalo bi uzeti da bi svaka stranka snosila svoje posebne troškove koji bi se odnosili na utvrđivanje premisa za donošenje odluke o osnovi zahtjeva koji bi nastali prije zaključenja nagodbe ${ }^{45}$ te razmjerni dio "zajedničkih" troškova postupka koji je tome prethodio za koji bi se moglo ocijeniti da bi se odnosio na utvrđivanje navedenih premisa (arg. ex 159/1.). U obrazloženju odluke kojom bi odlučio o visini zahtjeva sud bi mogao konstatirati sudbina kojih bi se od navedenih troškova smatrala riješenom i zašto međunagodbom.

\subsection{Djelomična nagodba}

Djelomična nagodba je nagodba koja je zaključena o dijelu zahtjeva ili o nekom od više istaknutih zahtjeva, odnosno nagodba koja je u cijelosti ili djelomično zaključena o predmetu spora u odnosu na nekog od suparničara (arg. ex 164/5., 165., 321/2., 329.). ${ }^{46}$

$\mathrm{U}$ postjugoslavenskoj doktrini ${ }^{47}$ izneseno je u vezi s naknadom troškova u slučaju djelomične nagodbe mišljenje da se pravilo da svaka stranka snosi svoje troškove primjenjuje i kad se one ne sporazumiju o troškovima u povodu nagodbe zaključene o jednom od više spojenih zahtjeva te da primjenu toga pravila treba razumjeti tako da će svaka od stranaka snositi svoje troškove koji se odnose samo na taj zahtjev i razmjerni dio troškova učinjenih za sve zahtjeve, pri čemu bi se taj razmjer određivao prema odnosu vrijednosti tog zahtjeva i ukupne vrijednosti svih zahtjeva. S ovim se mišljenjem u načelu valja složiti, s time da bi se ono trebalo na odgovarajući način primijeniti i u slučaju u kojemu bi se djelomična nagodba ticala dijela jednog zahtjeva, odnosno samo nekog od više suparničara. U okviru tog mišljenja ostalo bi, međutim, otvoreno pitanje bi li sud uopće trebao donijeti i, ako bi trebao, kakvu odluku o troškovima postupka u povodu djelomične nagodbe. ${ }^{48}$

44 Takva bi dispozicija u sudskoj nagodbi funkcionalno odgovarala odluci suda u međupresudi kojom bi on izrekao da se odluka o troškovima ostavlja za kasniju presudu (165.).

45 Na primjer, to bi mogli biti troškovi posebnog vještačenja.

46 O djelomičnoj presudi usporedi Triva, Dika, op. cit. u bilj. 1, str. 598 - 592; Dika, op. cit. u bilj. 1, str. 91 i slj.

47 Poznić, op. cit. u bilj. 25, str. 345.

48 U austrijskoj je doktrini (Bydlinski, op. cit. u bilj. 20, str. 699) s aspekta austrijskog prava izraženo shvaćanje da pitanje troškova ostaje otvorenim i kad glavna stvar nije 
U postjugoslavenskoj doktrini zastupa se i shvaćanje da bi u slučaju u kojemu bi stranke zaključile djelomičnu sudsku nagodbu kojom se ne bi dogovorile o naknadi parničnih troškova nastalih u vezi s dijelom spora koji je njome riješen, sud morao o parničnim troškovima koji se odnose na dio tužbenog zahtjeva ili tužbeni zahtjev o kojemu su zaključili sudsku nagodbu odlučiti po stavku 1. članka 159. ZPP-a, a o drugim troškovima u skladu s drugim pravilima o naknadi troškova. ${ }^{49}$ Ovo bi stajalište trebalo precizirati (korigirati) u smislu da bi u slučajevima u kojima bi neki od troškova bili zajednički za dio zahtjeva ili zahtjev o kojemu je zaključena nagodba i za dio zahtjeva ili zahtjev čija sudbina njome ne bi bila riješena ${ }^{50}$, trebalo za svaki od njih odrediti u kojem bi se dijelu odnosio na dio zahtjeva ili zahtjev o kojemu je zaključena nagodba i o sudbini tog dijela zauzeti stav primjenom odredbe stavka l. članka 159. ZPP-a, a o troškovima koji bi se ticali preostalog dijela zahtjeva odnosno preostalog zahtjeva odlučiti primjenom za taj dio mjerodavnim pravilima u skladu s načinom na koji bi bila riješena njegova postupovna sudbina. Pritom, možebitnom odlukom kojom bi se odlučilo o naknadi troškova postupka koji bi se odnosili da zahtjev ili dio zahtjeva koji ne bi bio obuhvaćen nagodbom, ne bi trebalo u njezinoj izreci odrediti da svaka stranka snosi svoje troškove koji bi se ticali zahtjeva ili dijela zahtjeva o kojemu je zaključena djelomična nagodba. Donošenjem takve odluke

u cijelosti riješena nagodbom (djelomična nagodba) jer tada ne može doći do učinka načelo koje proizlazi iz § 47. öZPO-a (vidi bilj. 11) da cijela stvar treba biti konačno riješena. Stoga, u slučaju dvojbe treba uzeti da će tek s konačnom odlukom doći do konačno važećeg uređenja troškova i da stranke, ne ističući troškove s obzirom na dio tražbine o kojemu su se sporazumjele, nisu zatražile i njihovu naknadu, osobito stoga što je, prema svim pravilima, teško moguće utvrditi koje od do tada nastalih troškova treba pripisati (riješenom) dijelu zahtjeva, a koliko preostalom predmetu spora. Čini se da bi ovo mišljenje bilo teško prihvatiti i s aspekta austrijskog prava, među ostalim i zato što se i prema tom pravu pitanje troškova postupka u slučaju djelomične nagodbe ne samo može već i treba smatrati riješenim njezinim zaključenjem.

Betetto, op . cit. u bilj. 9, str. 49, prema kojoj bi sud, ako bi, primjerice, tužitelj u parnici za naknadu štete utužio 1.100.000,00 po osnovi neimovinske štete i 500.000,00 po osnovi imovinske štete, pa bi stranke zaključile nagodbu o imovinskoj šteti, morao u izreci rješenja koje bi bilo sadržano u konačnoj presudi navesti da glede tužbenog zahtjeva o kojemu su stranke zaključile sudsku nagodbu $(500.000,00)$ svaka stranka snosi svoje troškove i nakon toga odmjeriti troškove po načelu uspjeha za zahtjev od 1.000.000,00.

50 Kao, na primjer, u slučaju u kojemu su sudske pristojbe odmjerene prema ukupnoj vrijednosti predmeta spora do koje se došlo zbrajanjem vrijednosti pojedinih zahtjeva - članci 21. i 23. ZSP-a. 
sud bi išao ultra petita. ${ }^{51}$ On bi, naime, u obrazloženju odluke kojom bi odlučio o zahtjevu za naknadu troškova koji bi se ticali zahtjeva ili dijela zahtjeva koji ne bi bio obuhvaćen sudskom nagodbom eventualno tek trebao konstatirati da se smatra da svaka stranka snosi svoje troškove nastale u vezi sa zahtjevom ili dijelom zahtjeva o kojemu su sklopili nagodbu - svakako ako samom nagodbom ne bi bilo što drugo određeno (arg. ex 159/1.).

Ako bi nagodbom spor bio u cijelosti riješen u odnosu na nekog od suparničara, za prosuđivanje prava na naknadu troškova dijela postupka koji bi se ticao tog suparničara bile bi mjerodavne odredbe članka 159. ZPP-a. To znači da bi se smatralo da suparničar koji je sklopio nagodbu i protivna stranka snose svoje troškove postupka u dijelu u kojemu bi se on odnosio na tog suparničara, ako u nagodbi ne bi bilo drukčije ugovoreno (159/1.). Ti bi troškovi obuhvaćali posebne troškove koji bi se ticali isključivo tog suparničara, ali i razmjeran dio troškova koji bi bili zajednički za sve suparničare. U slučaju u kojemu bi prije pokretanja parničnog postupka bio proveden neuspjeli postupak radi zaključenja izvanpanrične nagodbe, pa bi u naknadno pokrenutom parničnom postupku spor u odnosu na nekog od suparničara bio riješen nagodbom koja bi bila zaključena u tom postupku, trebalo bi na troškove prethodno provedenog neuspjelog postupka radi sklapanja izvanparnične nagodbe (324.), budući da i oni ulaze u parnične troškove (159/2.), primijeniti na odgovarajući način, s jedne strane, opća pravila o naknadi tih troškova u parničnom postupku (vidi infra ad IV.4.), a, s druge strane, ono što je rečeno o troškovima postupka u slučaju zaključenja djelomične nagodbe samo u odnosu na nekog od suparničara (vidi supra).

\section{Troškovi neuspjelog postupka za sklapanje izvanparnične nagodbe kao parnični troškovi}

O troškovima postupka neuspjelog izvanparničnog nagodbenog postupka kao parničnim troškovima vidi infra ad IV.4.

\section{Sudska nagodba kojom se rješavaju sporovi o kojima se vode odvojene parnice}

Kad se između istih stranaka vodi više parnica, nisu rijetki slučajevi da se sudskom nagodbom zaključenom u jednoj od parnica riješe i sporovi o kojima

51 Ako bi koja od stranaka zatražila da sud odluči i o troškovima koji bi se ticali zahtjeva ili dijela zahtjeva o kojemu je zaključena sudska nagodba, taj bi zahtjev trebalo odbaciti jer bi o njemu bilo na presumptivan način odlučeno tom nagodbom (vidi supra ad II.1.). 
su se vodile ostale parnice. Ako stranke pritom o troškovima svih tih postupaka ne bi u zaključenoj nagodbi nešto drugo utanačile, u načelu bi svaka stranka u tim postupcima snosila svoje troškove (arg. ex 159/1.). ${ }^{52}$

Ako bi stranke nagodbom sklopljenom $\mathrm{u}$ jednom postupku dogovorile da će jedna od njih ili svaka od njih povući tužbu ili se odreći tužbenog zahtjeva u drugim postupcima u kojima nastupaju kao tužitelji i ako pritom o naknadi troškova postupka u tim postupcima ne bi ništa posebno ugovorile, pitanje naknade troškova u tim postupcima u kojima bi došlo do povlačenja tužbe odnosno do odricanja od tužbenog zahtjeva trebalo bi prosuđivati primjenom odredaba članka 158. stavaka 1. i 2. ZPP-a. To znači da bi u pravilu tužitelj koji bi povukao tužbu ili se odrekao tužbenog zahtjeva bio dužan tuženiku naknaditi troškove postupka (158/1.). Međutim, iznimno od toga pravila, ako bi tužitelj povukao tužbu ili se odrekao tužbenog zahtjeva odmah nakon što bi tuženik udovoljio zahtjevu tužitelja ili zbog drugih razloga koji se mogu pripisati tuženiku, troškove postupka bio bi dužan tužitelju naknaditi tuženik (158/2.). U slučajevima o kojima je riječ o uspjehu stranaka prema zaključenoj nagodbi u dijelu u kojemu bi se odnosila na postupak u kojemu bi tužitelj povukao tužbu ili bi se odrekao tužbenog zahtjeva, ovisila bi i ocjena u kojoj bi mjeri trebalo uzeti da je tužitelj povukao tužbu ili da se odrekao tužbenog zahtjeva iz razloga koji se mogu pripisati svakoj od stranaka.

\section{Utjecaj sudske nagodbe na odluke o naknadi troškova postupka koje su donesene prije njezina zaključenja}

Prema odredbi reč. 2. stavka 1. § 149. ZSPGP-a, odredba reč. l. stavka 1. $\S$ 149. ZSPGP-a, prema kojoj se smatralo da su troškovi sklopljene nagodbe (poravnanja) uzajamno prebijeni, ako u njoj nije što drugo bilo uglavljeno, vrijedila je i za troškove u parnicama koje su "poravnanjem svršene", ako njihova naknada nije već jednoj stranci dosuđena pravomoćnom odlukom, a o toj dosudi ne bi ništa u nagodbi bilo spomenuto. ${ }^{53}$

U ZPP-u 76, jednako kao ni u ZPP-u 56, nema odredbe koja bi odgovarala odredbi § 149. stavka 1. reč. 2. ZSPGP-a.

U doktrini utemeljenoj na ZPP-u 76 i njegovim postjugoslavenskim derivatima koji su zadržali odredbe toga Zakona o troškovima postupka u slučaju okončanja spora zaključenjem sudske nagodbe, u pogledu mogućnosti da se odredba članka 159. ZPP-a, prema kojoj će svaka stranka snositi svoje troškove ako

52 Tako s aspekta slovenskog prava Betetto, op. cit. u bilj. 9, str. 392.

53 Vidi supra ad I. Ove su odredbe korespondirale odredbama § 46. öZPO-a; vidi bilj. 8. 
nagodbom nije drukčije ugovoreno, primijeni na odluke donesene prije njezina zaključenja, zauzeta su dva stajališta koja se značajno razlikuju od rješenja koje je bilo utvrđeno u odredbama § 149. stavka 1. ZSPGP-a. Prema jednom od tih stajališta nagodba “ipak ne dira u rešenja kojima je, nezavisno od ishoda spora, izrečena obveza naknade troškova, osim ako stranke svojim izričitim sporazumom odrede drugačije." ${ }^{54}$ Prema drugom, iznimka od pravila da svaka stranka snosi svoje troškove ako je parnica završena sudskom nagodbom, a u njoj nije drukčije ugovoreno, bili bi samo troškovi koje je sud dosudio stranci tijekom parnice u skladu s načelom krivnje (156/1.). ${ }^{55}$ Prvo bi se stajalište razlikovalo od drugog u tome što prema prvom nagodba ne bi djelovala na odluke donesene prije njezina zaključenja ako one općenito ne bi ovisile o ishodu spora, dok prema drugom ona ne bi djelovala (samo) na odluke o naknadi troškova koje bi bile utemeljene na načelu krivnje ili slučaja koji se stranci dogodio. ${ }^{56}$

Iz izloženih doktrinarnih stajališta, a contrario, proizlazilo bi da bi prema njima nagodba djelovala na odluke donesene prije njezina zaključenja u smislu da bi svaka stranka snosila i one svoje troškove čija bi im naknada bila dosuđena na teret protivne stranke ako bi im bili dosuđeni odlukama koje bi ovisile o ishodu spora, odnosno ako ne bi bile utemeljene na načelu krivnje i slučaja koji se stranci dogodio - osim ako nagodbom ne bi bilo ugovoreno nešto drugo. ${ }^{57}$

54 Poznić, op. cit. u bilj. 25, str. 345.

55 Tako Betetto, op. cit. u bilj. 9, str. 49, pozivajući se na Triva, S.; Belajec, V.; Dika, M., Građansko parnično procesno pravo, Zagreb 1986., str. 384. Pritom ova autorica pod načelom krivnje podrazumijeva i odgovornost za slučaj stranke kojoj se dogodio. To je stajalište s aspekta ZPP-a 56 zastupao i Bazala, op. cit. u bilj. 32, str. 35, naglašavajući da se odredba da svaka stranka snosi svoje troškove ako u nagodbi nije drukčije ugovoreno može odnositi samo na one troškove glede kojih nije već odlučeno da ih jedna stranka ima naknaditi protivnoj stranci neovisno o ishodu parnice, aludirajući pritom na odredbu članka 145. stavka 1. ZPP-a 56, prema kojoj je stranka bila dužna da nezavisno od ishoda parnice naknadi protivnoj stranci troškove koje je prouzrokovala svojom krivnjom ili slučajem koji joj se dogodio.

56 Razlika između navedenih stajališta bila bi, međutim, praktično zanemariva jer se tijekom parničnog postupka posebne odluke kojima se nameće obveza jednoj od stranaka da naknadi troškove postupka drugoj donose samo u slučajevima u kojima ima mjesta njihovoj dosudi po načelu krivnje odnosno slučaja koji se jednoj od njih dogodio (156/1.).

57 Nagodba u kojoj ne bi bilo drukčije ugovoreno ne bi djelovala ni na odluke o naknadi troškova postupka koje bi bile sadržane u međupresudi ili djelomičnoj presudi koje bi prije njezina zaključenja bile donesene tijekom postupka. Takva se nagodba, naime, ne bi se ticala dijela predmeta spora (kod međupresude - kvalitativno određenog, kod djelomične presude - i kvalitativno i kvantitativno određenog) o kojemu bi njima bilo odlučeno. 
Razlike između izloženih stajališta koja se zastupaju u doktrini utemeljenoj na ZPP-u 76 i odredbe reč. 2. stavka 1. § 149. ZSPGP-a bile bi značajne. Prema navedenoj odredbi § 149. ZSPGP-a nagodba kojom nešto drugo ne bi bilo ugovoreno djelovala bi na sve odluke o naknadi troškova postupka koje su donesene prije njezina zaključenja koje do tada nisu postale pravomoćne - neovisno o tome bi li njihovo donošenje ovisilo o ishodu spora, odnosno bi li bile utemeljene na načelu krivnje ili slučaja koji se stranci dogodio. Samo ako bi te odluke do momenta zaključenja nagodbe postale pravomoćne, nagodba ne bi na njih djelovala. Prema izloženim stajalištima, međutim, nastupanje pravomoćnosti odluka o naknadi troškova prije zaključenja nagodbe ne bi bilo relevantno ona na njih ne bi djelovala ako njome nešto drugo ne bi bilo predviđeno, ali samo ako ne bi ovisile o ishodu spora, odnosno ako bi bile donesene u skladu s odredbom članka 156. stavka 1. ZPP-a. Na druge bi odluke nagodba kojom nešto drugo ne bi bilo ugovoreno djelovala neovisno o tome bi li ili ne bi prije njezina zaključenja stekle svojstvo pravomoćnosti.

U vezi s naznačenim problemom djeluje li i kako sudska nagodba na odluke o troškovima postupka koje su donesene prije njezina zaključenja bilo bi, de lege lata, teorijski gledano, moguće zastupati barem dvije interpretativne varijante.

Prema jednoj od njih, budući da u Zakonu nema posebne odredbe koja bi ograničavala pravni učinak prije nagodbe donesenih odluka o naknadi troškova postupka samo na one od njih koje su postale pravomoćne, trebalo bi zauzeti stajalište da bi u načelu odluke kojima bi jednoj od stranaka bila nametnuta dužnost da naknadi neke troškove protivnoj stranci ostale na snazi, osim ako nagodbom ne bi bilo drukčije (izravno ili posredno) ugovoreno. To bi svakako vrijedilo za odluke o naknadi troškova po načelu krivnje ili slučaja koji se stranci dogodio (156.). Naime, odluka o naknadi troškova po tim dvjema osnovama ne ovisi o meritornom ishodu parnice, pa tako ni o nagodbi kojom je okončan spor o kojemu se ona vodi. To bi, međutim, trebalo vrijediti i za druge odluke kojima bi pitanje naknade nekih troškova bilo riješeno odlukama koje ne bi ovisile o konačnom ishodu spora. Eventualno bi domašaj ovog tumačenja bilo moguće, kako je to došlo do izražaja u supra izloženim doktrinarnim stajalištima u bivšoj jugoslavenskoj i postjugoslavenskoj doktrini, ograničiti u smislu da bi sudska nagodba djelovala samo na odluke o naknadi troškova koje bi ovisile o meritornom ishodu spora - ako njome ne bi što drugo bilo ugovoreno.

Druga bi interpretativna mogućnost polazila od toga da sudska nagodba ima učinke pravomoćne odluke - značenje procesne smetnje (323.) te da utvrđenjem određenih prava i obveza stranaka djeluje prejudicijelno pro futuro. Zato bi, ako bi se pošlo od doslovnog značenja odredbe prema kojoj se smatra da je nagodbom riješeno pitanje troškova postupka u parnici koja je njome okončana u smislu da svaka stranka snosi svoje troškove, osim ako njome ne bi nešto drugo bilo 
ugovoreno (159/1.), trebalo uzeti da bi njome bili obuhvaćeni i troškovi koji bi bili dosuđeni odlukama koje bi bile donesene prije njezina zaključenja neovisno o tome jesu li one stekle svojstvo pravomoćnosti - pravna snaga pravomoćnosti koja se veže uz sudsku nagodbu bila bi jača od pravne snage prije njezina zaključenja donesenog ne samo nepravomoćnog već i od pravne snage pravomoćnog rješenja o naknadi troškova postupka (res iudicialiter transacta posterior deragat rei iudicatae priori). Ovo bi stajalište svoje uporište moglo naći u okolnosti da su i austrijski i starojugoslavenski zakonodavac smatrali da je, da bi se djelovanje presumpcije iz odredbe § 47. stavka 1. reč. 1. öZPO-a i § 149. stavak 1. reč. 1. ZSPGP-a (vidi supra ad I.) ograničilo u odnosu na neke od odluka o naknadi troškova koje bi bile donesene prije njezina zaključenja, bilo nužno izrijekom propisati da se ta ograničenja tiču samo odluka koje su prije toga postale pravomoćne jer bi se inače smatralo da se odnose na sve odluke koje su prije toga donesene.

Opredjeljenje za jednu od dviju supra navedenih interpretativnih mogućnosti ovisilo bi zapravo o značenju koje bi se pridalo predmnjevi sadržanoj u odredbi članka 159. stavka 1. ZPP-a, predmnjevi da će svaka stranka snositi svoje troškove, ako u nagodbi nije drukčije ugovoreno - o tome hoće li se uzeti da se ta predmnjeva odnosi na troškove cjelokupnog postupka koji je prethodio nagodbi, neovisno o tome je li o njihovoj naknadi prethodno doneseno posebno rješenje, ili samo na one od tih troškova o kojima takvo rješenje nije doneseno, prema jednoj od interpretativnih podvarijanti uz ograničenje da njihova dosuda nije ovisila o ishodu spora.

Čini se zapravo da bi navedeno interpretativno stajalište zauzeto u bivšoj jugoslavenskoj i postjugoslavenskoj doktrini da predmnjeva iz odredbe članka 159. stavka 1. ZPP-a djeluje na odluke o naknadi troškova postupka koje su donesene prije zaključenja nagodbe samo ako ne ovise o konačnom ishodu spora bilo prihvatljivo i de lege lata. Moglo bi se ipak, eventualno, zastupati i shvaćanje da bi to stajalište trebalo prihvatiti uz ograničenje da bi (iz pragmatičnih razloga) domašaj predmnjeve o kojoj je riječ trebalo općenito ograničiti na odluke koje prije zaključenja nagodbe nisu postale pravomoćne i/ili ovršne, dakle prihvatiti soluciju iz § 47. öZPO-a i § 149. ZSPGP-a, ali je proširiti i na ovršne odluke. Ratio navedenog ograničenja trebalo bi tražiti u okolnosti da bi prethodno donesena pravomoćna i ovršna rješenja o naknadi troškova postupka mogla proizvesti učinke čije bi naknadno otklanjanje u povodu nagodbe koja bi djelovala na te odluke moglo u praksi dovesti do ozbiljnih komplikacija - do pokretanja i vođenja restitucijskih, opozicijskih itd. parnica, dakle ne samo do povećanog opterećenja sudova, već i do ugrožavanja pravne sigurnosti.

Iz navedenih razloga valjalo bi, eventualno, prigodom neke od sljedećih revizija (reformi) zakonskog uređenja parnične procedure izrijekom riješiti i 
pitanje djelovanja nagodbe na odluke o troškovima postupka koje su donesene prije njezina zaključenja.

Drukčija odredba u nagodbi o troškovima o čijoj je naknadi prethodno odlučeno tijekom postupka imala bi značenje naknadne okolnosti koja bi dovodila do prestanka ili promjene sadržaja tražbina utvrđenih u odlukama kojima je to učinjeno, mogla bi biti osnovom za isticanje tzv. opozicijskih prigovora u eventualnom ovršnom postupku (50/1.9. OZ-a). ${ }^{58}$

\section{TROŠKOVI POSTUPKA ZA SKLAPANJE IZVANPARNIČNE NAGODBE}

\section{Općenito}

Institut izvanparnične nagodbe, kako je to već rečeno supra ad I., uređen je odredbama članka 324. ZPP-a. Osoba koja namjerava podići tužbu može preko nižeg prvostupanjskog suda na čijem području protivna strana ima prebivalište pokušati postići nagodbu (324/1.). Sud kojem je takav prijedlog upućen pozvat će protivnu stranku i upoznati je s prijedlogom o nagodbi (324/2.). Troškove tog "postupka podmiruje podnosilac prijedloga" (324/3.).

U vezi s troškovima nastalim u postupku za zaključenje nagodbe o kojoj je riječ potrebno je razlikovati dvije situacije. Jedna postoji kada su stranke zaključile takvu nagodbu (vidi infra ad III.3.), druga kad u tome nisu uspjele (vidi infra ad III.4.).

\section{Struktura troškova izvanparničnog nagodbenog postupka}

Troškove stranaka u izvanparničnom nagodbenom postupku mogu činiti odvjetnički troškovi, npr. troškovi za sastavljanje prijedloga kojim se taj postupak pokreće, troškovi sastavljanja možebitnog odgovora na taj prijedlog, troškovi zastupanja stranaka na ročištu za pokušaj nagodbe. Tijekom tog postupka mogu se izvesti, radi pripremanja osnove za moguću nagodbu, i neki dokazi, npr. vještačenje itd., pa bi i troškovi koji bi time bili izazvani ulazili u troškove toga postupka.

58 OZ: Ovršni zakon (Narodne novine, br. 112/2012, 25/2013, 93/2014, 55/2016, 73/2017). Prema odredbi članka 50. stavka 1. t. 9. OZ-a ovršenik može protiv rješenja o ovrsi izjaviti žalbu i ako je tražbina prestala na temelju činjenice koja je nastala u vrijeme kad je ovršenik više nije mogao istaknuti u postupku iz kojeg potječe odluka, odnosno nakon zaključenja sudske ili upravne nagodbe ili sastavljanja, potvrđivanja ili ovjeravanja javnobilježničke isprave. 


\section{Troškovi postupka u kojemu je zaključena izvanparnična nagodba}

Prema odredbi članka 324. stavka 3. ZPP-a troškove izvanparničnog nagodbenog postupka "podmiruje podnosilac prijedloga". Tu bi odredbu bilo moguće različito protumačiti. Prema jednom stajalištu izraženom u postjugoslavenskoj doktrini, koje se poziva na odredbu članka 324. st. 3. u vezi s odredbom članka 159. st. 2. ZPP-a, u slučaju u kojemu bi se pokušaj nagodbe okončao bezuspješno, podnositelj prijedloga snosio bi svoje troškove i bio bi dužan naknaditi troškove drugoj strani. Pritom, ako bi parnica koja bi poslije toga bila pokrenuta završila njegovom pobjedom, svi bi izdaci koje bi imao u povodu pokušaja nagodbe činili dio parničnih troškova na čiju bi naknadu imao pravo. ${ }^{59}$ Izloženo stajalište ostalo je nedorečeno zato što se u okviru njega nije odgovorilo i na pitanje bi li i u kojem smislu navedeno tumačenje sintagme "podmiruje podnosilac prijedloga" utjecalo na pravo druge stranke da u izvanparničnom nagodbenom postupku traži od predlagatelja naknadu svojih troškova toga postupka i u slučaju u kojemu bi nagodba bila zaključena - bi li u tom slučaju trebalo primijeniti odredbu članka 159. stavka 1. ZPP-a po kojoj svaka stranka snosi svoje troškove ako je parnica završena sudskom nagodbom, a u nagodbi ne bi drukčije bilo ugovoreno, ili bi, osim ako drukčije ne bi bilo ugovoreno, unatoč tome što bi nagodba bila zaključena, podnositelj prijedloga bio dužan drugoj strani naknaditi troškove koje bi ona imala u tom postupku. Naime, tumačenje sintagme da troškove izvanparničnog nagodbenog postupka "podmiruje podnosilac prijedloga" (doduše ako ne dođe do nagodbe) o kojemu je riječ kao da bi, arg. a cohaerentia, a completudine, govorilo u prilog drugoj interpretativnoj mogućnosti.

Prema drugom mogućem tumačenju, također utemeljenom na odredbama članka 324. st. 3. i članka 159. st. 2. ZPP-a, koje se čini prihvatljivijim od prethodno izloženog, u načelu bi se i u slučaju u kojemu bi stranke zaključile izvanparničnu nagodbu smatralo da svaka od njih snosi svoje troškove koje je imala (prethodno snosila) u tom postupku, osim ako u nagodbi ne bi bilo drukčije ugovoreno. Stoga bi, ako stranke ne bi drukčije ugovorile, odredbu prema kojoj podnositelj prijedloga kojim je pokrenut izvanparnični nagodbeni postupak podmiruje troškove toga postupka (324/3.) trebalo shvatiti u smislu da bi podnositelj prijedloga snosio troškove koje bi imao u vezi s podnošenjem prijedloga i sudjelovanjem na ročištu na kojemu bi nagodba bila zaključena te eventualno druge troškove za pokriće kojih bi predujmio ili bio dužan predujmiti sredstva tijekom nagodbenog postupka, dok bi druga stranka snosila svoje troškove sudjelovanja u tom postupku.

59 Tako zapravo Poznić, op. cit. u bilj. 25, str. 743. 
U prilog drugog navedenog tumačenja govorilo bi više razloga. Prvo, ono bi odgovaralo općem pravnom pravilu iz § 20. stavka 1. ZSVP-a ${ }^{60}$ prema kojemu, ako u tom "zakonu nije što drugo naređeno, u vanparničnom postupku troškove snosi stranka u čijem je interesu postupak poveden”. Treba, naime, uzeti da se postupak radi nagodbenog prevladavanja spora pokreće u interesu obiju stranaka, a ne samo u interesu predlagatelja. Drugo, nema razloga zbog kojega bi u pogledu prethodnog, ali i konačnog snošenja troškova izvanparničnog nagodbenog postupka vrijedila različita pravila od onih koja bi vrijedila kad bi se incidentalni nagodbeni postupak pokrenuo u okviru parničnog postupka (159., 321., 324.), dakle od pravila prema kojima svaka od stranaka svoje troškove takvog neuspjelog incidentalnog postupka može ostvarivati samo kao troškove parničnog postupka. Treće, sudjelovanje u izvanparničnom nagodbenom postupku je dobrovoljno: protivna stranka može prihvatiti prijedlog za provedbu toga postupka, ali ne mora - o njezinoj dispoziciji u cijelosti ovisi hoće li sudjelovati u tom postupku. Pritom, ako ne prihvati prijedlog za njegovu provedbu, među ostalim i ignoriranjem toga prijedloga, za nju ne mogu u tom postupku nastupiti nikakve štetne posljedice, npr. one koje bi je pogodile ako ne bi aktivno sudjelovala u parničnom postupku. ${ }^{61}$ Budući da bi u cijelosti o njezinoj "dobroj volji” ovisilo hoće li sudjelovati u tom postupku, ne bi u načelu ni smjela moći tražiti naknadu troškova koji bi joj nastali zato što bi u njemu sudjelovala (volenti non fit iniuria). Upravo stoga obje stranke, dakle ne samo predlagatelj, već i protivna stranka, mogu u naknadnom parničnom postupku tražiti naknadu troškova koje su imale u izvanparničnom nagodbenom postupku koji nije uspio kao da je riječ o parničnim troškovima (159/2.) (vidi infra ad III.4.). U neuspjelom izvanparničnom nagodbenom postupku stranka bi imala eventualno pravo tražiti od druge stranke samo naknadu troškova koje bi joj ova prouzrokovala svojom krivnjom ili slučajem koji bi joj se dogodio (arg. ex 156., vidi supra ad II.8.). Četvrto, rješenje prema kojemu bi predlagatelj bio dužan snositi troškove sudjelovanja protivne stranke u izvanparničnom nagodbenom postupku neovisno o tome hoće li se nagodba sklopiti djelovalo bi destimulativno na korištenje takve mogućnosti prevladavanja sporova, što bi bilo u protivnosti s načelnim pravnopolitičkim stavom da treba poticati razne oblike mirnog rješavanja sporova (arg. ex 186.d do 186.g. 288.a/1., 324.).

60 ZSVP: Zakon o sudskom vanparničnom postupku, Službene novine od 1. 8. 1934., br. 175-LV.

61 Zbog njezine pasivnosti protiv nje bi u parničnom postupku mogla biti donesena presuda zbog ogluhe (331.b). 


\section{Izvanparnična nagodba kojom su riješeni i sporovi koji su predmet posebnih parničnih postupaka}

O utjecaju izvanparnične nagodbe na troškove parničnih postupaka koji se tiču sporova koji su njome riješeni vrijedilo bi, mutatis mutandis, ono što je rečeno o parničnoj nagodbi kojom su riješeni sporovi koji su predmet drugih parnica - vidi supra ad II.7.

\section{Troškovi neuspjelog izvanparničnog nagodbenog postupka kao parnični troškovi}

Prema odredbi članka 159. stavka 2. ZPP-a troškovi "nagodbe koja je pokušana (članak 324.), ali nije uspjela ulaze u parnične troškove”. Ova je uopćeno redigirana odredba koja se tiče troškova izvanparnične nagodbe u postjugoslavenskoj doktrini različito protumačena, odnosno bilo bi je moguće različito protumačiti.

Prema jednom stajalištu izraženom u doktrini stranka kojoj je bezuspješni pokušaj nagodbe prouzrokovao troškove (čl. 324.) može zahtijevati njihovu naknadu kao dio parničnih troškova ako je u parnici imala uspjeha. ${ }^{62}$ Riječ je o stajalištu koje bi se u svojoj načelnoj (evazivnoj) apstraktnosti činilo prihvatljivim, koje bi, međutim, bilo primjereno samo nekim od mogućih situacija koje bi se u praksi mogle javiti. Naime, doslovno prema tom stajalištu, stranka koja bi snosila troškove bezuspješnog izvanparničnog nagodbenog postupka (324/3.) imala bi pravo da zahtjevom za naknadu troškova parničnog postupka, koji bi pokrenula nakon što taj prethodno inicirani izvanparnični postupak ne bi uspio, obuhvati i troškove toga postupka kao da su nastali u parničnom postupku neovisno o tome kakvu je nagodbu u njemu predlagala, pri čemu bi njezino pravo na naknadu i tih troškova ovisilo (samo) o njezinu uspjehu u parnici (154.).

62 Usporedi Poznić, op. cit. u bilj. 25, str. 345. Prema ovom autoru (str. 742) ako se "pokušaj poravnanja okonča bezuspešno, podnosilac predloga snosi svoje troškove i dužan je naknaditi troškove drugoj strani (čl. 324. st. 3. u vezi s čl. 159. st. 2.)”, a ako "se parnica koja posle toga bude pokrenuta završi njegovom pobedom, svi izdaci koje je imao povodom pokušaja poravnanja čine deo parničnih troškova za koje on ima pravo na naknadu.". Slično i Prančić, V., O naknadi pretprocesnih troškova u parničnom postupku, Zbornik Pravnog fakulteta u Splitu, vol. 47, br. 4, 2010., str. 871 i 872, koji smatra da u slučaju neuspjelog pokušaja nagodbe troškovi koje je prethodno snosio podnositelj prijedloga za sklapanje nagodbe, u smislu odredbe članka 324. stavka 3. ZPP-a, ulaze u parnične troškove (159/2.) "time da se o naknadi ovih troškova odlučuje s obzirom na uspjeh stranaka u parnici (članak 154. ZPP-a)”. 
Prema drugom od mogućih tumačenja odredbe članka 159. stavka 2. u vezi s člankom 324. stavka 3. ZPP-a prigodom donošenja odluke o tome naknadu kojih bi troškova prethodno bezuspješno provedenog izvanparničnog nagodbenog postupka stranka koja ih je prethodno snosila imala pravo tražiti u parničnom postupku, trebalo bi uzeti u obzir ono što je ta stranka predložila kao ono na što je bila spremna pristati u slučaju zaključenja nagodbe ${ }^{63}$, ono što bi naknadno zatražila u tužbi kojom je pokrenula parnicu u kojoj je postavila zahtjev za naknadu tih troškova te ono što bi joj bilo dosuđeno u parničnom postupku. Ako bi se njezin prijedlog nagodbenog rješenja spora, treba uzeti konačni koji bi iznijela tijekom izvanparničnog nagodbenog postupka ${ }^{64}$, i njezin tužbeni zahtjev sadržajno u bitnome podudarali, ne bi bilo razloga da joj se troškovi bezuspješnog prethodno provedenog nagodbenog postupka ne priznaju u skladu s njezinim uspjehom u parničnom postupku. Ako se, međutim, taj prijedlog i kasnije istaknuti tužbeni zahtjev ne bi (kvalitativno i/ili kvantitativno) podudarali te ako bi se moglo zaključiti da nagodba nije uspjela zbog te nepodudarnosti ${ }^{65}$, stranci koja je podmirila troškove prethodnog nagodbenog postupka u načelu ne bi trebalo priznati pravo da naknadu tih troškova traži u parničnom postupku - u tom bi slučaju trebalo uzeti da je ona dala povod za neuspjeh prethodno iniciranog nagodbenog postupka i da bi trebala konačno snositi troškove koje je u njemu imala. Ovo bi tumačenje bilo u skladu s općim načelom troškovnog materijalnog prava da vlastite troškove treba definitivno snositi, ali i protivnoj stranci naknaditi njezine troškove ona stranka koja je dala povod za vođenje glavnog ili incidentalnog postupka u kojemu su nastali. Bilo bi, naime, protivno načelu da su stranke dužne savjesno se koristiti pravima koja su im priznata Zakonom (9.), ali i dužnosti suda da onemogući svaku zloupotrebu

63 Iz načina na koji su redigirane odredbe članka 324. ZPP-a proizlazilo bi da one impliciraju da osoba koja namjerava podnijeti tužbu može radi pokušaja nagodbe inicirati poseban sudski postupak (324/1.) prijedlogom o nagodbi s kojim će sud upoznati protivnu stranu (arg. ex 324/2., vidi supra ad III.1.), koji bi u bitnome sadržajno trebao odgovarati zahtjevu koji će ona istaknuti u tužbi. U tom je smislu u literaturi (Prančić, op. cit. u bilj. 62, str. 871) izneseno stajalište da se pokušaj "nagodbe poduzima podneskom u kojemu treba navesti sadržaj nagodbe koja se predlaže, na što upućuje tekst odredbe članka 324. stavka 2. ZPP-a, gdje se govori o 'upoznavanju s prijedlogom o nagodbi'”.

64 Taj bi se prijedlog mogao razlikovati od onoga sadržanog u prijedlogu kao podnesku kojim je izvanparnični nagodbeni postupak iniciran.

65 Pritom bi, svakako, trebalo voditi računa i o tome je li do kvalitativne i/ili kvantitativne razlike između prijedloga iznesenog u nagodbenom postupku i postavljenog tužbenog zahtjeva u parničnom postupku došlo zbog okolnosti koje su u međuvremenu nastupile. 
prava u postupku (10/1.1.) - ako bi se stranci koja je "skrivila" neuspjeh jednog prethodnog postupka priznalo pravo da traži naknadu troškova toga postupka u naknadnom parničnom postupku samo zato što taj prethodni postupak nije uspio, neovisno o razlozima zbog kojih je do toga došlo, dakle čak i kad bi ona za to bila odgovorna. Drukčije tumačenje bilo bi protivno i zahtjevima javnog morala (arg. ex 3/3.), bilo bi nepravično ${ }^{66}$ i nepošteno.

Ako se iz prijedloga za provedbu izvanparničnog nagodbenog postupka, sadržanog u inicijalnom podnesku ili kasnije istaknutog tijekom toga postupka, ne bi moglo pouzdano utvrditi kakvu je nagodbu predlagatelj (u naknadnom parničnom postupku - redovito tužitelj) nudio, odnosno na što je bio spreman pristati, ne bi mu u parničnom postupku trebalo priznati naknadu troškova koje je imao u tom izvanparničnom postupku jer se ne bi moglo utvrditi odgovara li i u kojoj mjeri ono što se nudilo u izvanparničnom nagodbenom postupku uspjehu stranaka u parničnom postupku ${ }^{67}$ - rizik toga neuspjeha trebala bi snositi ta stranka.

Budući da bi i druga stranka u izvanparničnom nagodbenom postupku mogla imati troškove koje bi sama snosila (vidi supra ad III.2. i 3.), postavlja se pitanja bi li i ona u naknadnom parničnom postupku mogla tražiti njihovu naknadu kao troškova parničnog postupka. Na to pitanje bi svakako trebalo pozitivno odgovoriti, osobito u slučaju u kojemu bi naknadnu parnicu pokrenula ta stranka protiv predlagatelja iz izvanparničnog nagodbenog postupka. Takvo bi rješenje nužno proizlazilo iz elementarnih zahtjeva procesne ravnoteže i ravnopravnosti stranaka u građanskim sudskim postupcima, ali i zato što bi druga stranka u načelu trebala snositi svoje troškove sudjelovanja u tom postupku (vidi supra ad III.3.).

66 Prema odredbi članka 29. stavka 1. Ustava Republike Hrvatske (Narodne novine, br. 56/1990, 135/1997, 8/1998, 113/2000, 124/2000, 28/2001, 41/2001, 55/2001, 76/2010, 85/2010, 05/2014; URH) svatko ima pravo da zakonom ustanovljeni neovisni i nepristrani sud pravično i u razumnom roku odluči o njegovim pravima i obvezama, ili o sumnji ili optužbi zbog kažnjivog djela.

${ }^{67}$ Upravo bi se stoga moglo uzeti da stajalište izraženo u slovenskoj literaturi (Betetto, N.; Galič, A., u Ude, L.; Betetto, N.; Galič, A., Rijavec, V.; Wedam Lukić, D.; Zobec, J., Pravdni postopek, Zakon s komentarjem, 3. knjiga, Ljubljana, 2009., str. 48), utemeljeno na odredbama članaka 159. i 309. slovenskog ZPP-a iz 1999., koje se sadržajno doslovno podudaraju s odredbama članka 159. i 324. hrvatskog ZPP-a, prema kojemu se troškovi neuspjelog pokušaja zaključenja preventivne nagodbe, ako nakon takvog pokušaja bude podnesena tužba, smatraju troškovima (parničnog) postupka, u kojemu bi stranka koja bi u njemu uspjela mogla troškove ročišta za preventivnu nagodbu zahtijevati od protivne stranke, zapravo previđa složenost problema i ne pogađa bit stvari. 
Stranka koja bi u parničnom postupku zatražila naknadu troškova koje je imala u neuspjelom izvanparničnom nagodbenom postupku, imala bi pravo na naknadu samo onih od tih troškova koji su bili potrebni za njegovu provedbu (arg. ex 155/1.). ${ }^{68}$

\section{Troškovi neuspjelog incidentalnog nagodbenog postupka}

Iz odredbe prema kojoj troškovi nagodbe koja je pokušana (324.), ali nije uspjela ulaze u parnične troškove (159/2.), trebalo bi, argumento a minori ad maius, a completudine, a cohaerentiam, per analogiam, a fortiori, izvesti i zaključak da u parnične troškove ulaze i troškovi incidentalnog postupka za zaključenja sudske nagodbe iniciranog u okviru parničnoga postupka (321. - 323.). Na te bi troškove, mutatis mutandis, vrijedilo ono što je rečeno za troškove neuspjelog izvanparničnog nagodbenog postupka (vidi supra ad III.3.).

\section{Troškovi neuspjelog pokušaja izvansudske nagodbe}

S obzirom na to da prema odredbi članka 159. stavka 2. ZPP-a samo troškovi izvanparnične nagodbe koja je pokušana (324.), ali nije uspjela ulaze u parnične troškove, troškovi pokušane izvansudske nagodbe ne bi se mogli smatrati parničnim troškovima ${ }^{69}$ - te bi troškove sudionici takvog sporazuma mogli eventualno ostvarivati po općim pravilima za ostvarivanje imovinskopravnih zahtjeva. Vidi infra ad IV.

\section{IZVANSUDSKA NAGODBA O PREDMETU SPORA I NAKNADA TROŠKOVA POSTUPKA}

\section{Općenito}

Stranke mogu tijekom parničnog postupka izvansudskim sporazumom riješiti spor o kojemu teče taj postupak. Upravo se stoga i postavlja pitanje o mogućem utjecaju tog izvansudskog sporazuma na pravnu sudbinu parnice u vezi s kojom je sklopljen, uključujući i na prava stranaka na naknadu troškova u toj parnici.

68 Prema odredbi članka 155. stavka 1. ZPP-a sud će prilikom odlučivanja o troškovima postupka stranci odrediti naknadu samo onih troškova koji su bili potrebni za vođenje parnice.

69 Tako i Prančić, op. cit. u bilj. 62, str. 872. 
Izvansudski sporazum mogao bi višestruko utjecati na parnicu u vezi s kojom je sklopljen, pa time i na pravo stranaka na naknadu parničnih troškova. Ti učinci, pritom, zato što izvansudski sporazum o rješenju spora ima značenje privatnopravnog akta, ne bi mogli imati izravni procesnopravni učinak na parnicu u tijeku. Stipulacije stranaka u tom sporazumu mogu tek posredno utjecati na odluke koje će biti donesene u parničnom postupku - na isti način na koji, općenito uzevši, za to mogu biti relevantni pretparnični odnosno mimoparnični privatnopravni sporazumi. To znači da bi se stranke mogle tijekom prvostupanjskog postupka pozvati na postignuti izvanparnični sporazum o rješenju svojega spora sve dok bi u tom postupku mogle iznositi novote i da bi sud bio dužan taj sporazum uzeti u obzir prigodom donošenja svoje meritorne odluke kao i svaki drugi privatnopravni sporazum.

Stranke bi zatim mogle tijekom parničnog postupka, u skladu s postignutim izvansudskim sporazumom, poduzimati radnje kojima bi se parnični postupak trebao okončati - npr. povlačenjem tužbe ili odricanjem od tužbenog zahtjeva. U vezi s takvim postupovnopravnim dispozicijama moglo bi se postaviti pitanje bi li sud i kako mogao i trebao prigodom poduzimanja tih radnji uzeti u obzir njihov izvansudski sporazum (vidi infra ad IV.2.).

Izvansudskim sporazumom stranke bi se mogle obvezati da će taj svoj sporazum pretočiti u sudsku nagodbu, što otvara i pitanje odnosa tih dvaju akata (vidi infra ad IV.3.).

Odredbe članaka 150. do 159. ZOO-a ${ }^{70}$ o nagodbi ne uređuju izrijekom pitanje pravne sudbine troškova koji bi mogli nastati u vezi sa sklapanjem toga ugovora. Zato se može postaviti i pitanje bi li i u kojem smislu bilo moguće prigodom interpretacije izvansudskog sporazuma (nagodbe) o rješenju spora na odgovarajući način primijeniti odredbe o naknadi troškova u postupku okončanom sudskom nagodbom, dakle odredbe članka 159. ZPP-a (vidi infra ad IV.4.).

O tome mogu li troškovi pokušaja izvansudske nagodbe imati značenje parničnih troškova vidi infra ad V.6.

Stranke bi u načelu, kako je to supra rečeno, trebale moći sudskim putem, po općim pravilima o tome, ostvarivati svoja prava utvrđena izvansudskim sporazumom o rješenju spora, uključujući i pravo na naknadu troškova koje bi imale u vezi sa sklapanjem toga sporazuma.

70 Zakon o obveznim odnosima (Narodne novine, br. 35/2004, 41/2008, 125/2011, 78/2015, 29/2018; ZOO). 


\section{Utjecaj izvansudskog sporazuma o rješenju spora na naknadu troškova parničnog postupka}

Izvansudski sporazum koji bi stranke postigle o rješenju spora o kojemu teče prvostupanjski parnični postupak bio bi relevantna osnova za donošenje odgovarajuće odluke o zahtjevima o kojima bi trebalo odlučiti u tom postupku, svakako, ako, u skladu s tim sporazumom, ne bi došlo do povlačenja tužbe ili drukčijeg okončanja postupka u obliku meritorne sudske odluke, npr. presudom na temelju priznanja (331.) ili presudom na temelju odricanja (331.a). Ako bi izvansudskim sporazumom bilo izrijekom riješeno i pitanje naknade troškova sklapanja izvansudskog sporazuma i troškova parničnog postupka, npr. dispozicijom prema kojoj bi o tim troškovima trebao odlučiti sud u parničnom postupku u povodu kojega je taj sporazum sklopljen, tada bi on mogao biti osnova i za donošenje odgovarajuće odluke o tim troškovima, analogno kao i odgovarajuće utanačenje u sudskoj nagodbi ${ }^{71}$ (vidi supra ad II.3.) - osim ako se postupak ne bi okončao na neki drugi način.

Ako izvansudskim sporazumom kojim bi stranke izrijekom ili prešutno riješile (u cijelosti ili djelomično) spor o kojemu se vodi parnični postupak ne bi bilo drukčije ugovoreno, odnosno ako se drukčiji zaključak o tome ne bi mogao izvesti iz tog sporazuma, valjalo bi (arg. a cohaerentia, per analogiam ex 159/1.) uzeti da bi svaka stranka trebala snositi svoje troškove nastale u vezi s njegovim sklapanjem, ali i do tada nastale troškove parničnog postupka. Uz takav bi se sporazum (nagodbu), naime, vezale dvije predmnjeve. Jedna da se smatra da su se stranke njegovim sklapanjem suglasile da će svaka snositi svoje troškove koje je imala u vezi s njegovim sklapanjem i druga prema kojoj bi se smatralo da su se time suglasile i da će svaka od njih snositi svoje do tada nastale troškove u parničnom postupku koji se vodio o sporu koji su njime riješile. Ako bi stranke izvansudskim sporazumom samo djelomično riješile spor o kojemu se vodi parnični postupak, trebalo bi uzeti da bi domašaj navedenih predmnjeva odgovarao domašaju onih koje se vežu uz djelomičnu sudsku nagodbu (vidi supra ad II.5.3.). Razlika između učinaka sudske nagodbe i izvansudskog sporazuma

71 U tom smislu Bydlinski, op. cit. u bilj. 20, str. 699, s aspekta austrijskog prava ističe da bi se u slučaju u kojemu su stranke pravni spor riješile izvansudskim sporazumom i pritom utvrdile u njemu i uglavke o naknadi troškova, radilo o učinkovitom sporazumu koji bi trebalo prosuđivati prema općim načelima privatnog prava, za čiju bi provedbu put parnice bio dopušten. Pritom bi i doslovni tekst § 47. öZPO-a ("ako ništa drugo nije ugovoreno") dopuštao privatnopravnu dispoziciju o zahtjevima za naknadu troškova. Moglo bi se, međutim, primijetiti da se sintagma "ako ništa drugo nije ugovoreno” iz § 47. stavka 1. reč. 1. öZPO-a odnosi na sudsku nagodbu, a ne i na možebitne stipulacije izvan toga sporazuma. 
podudarnog sadržaja bila bi ipak $u$ tome što bi sud ovaj izvansudski sporazum tretirao kao svaku privatnopravnu dispoziciju o kojoj bi ovisila odluka o nekim od meritornih zahtjeva, uključujući i o onome o naknadi troškova postupka, dok bi predmnjeva sadržana u sudskoj nagodbi izravno djelovala snagom rei iudicatae. ${ }^{72}$

Ako bi u povodu izvansudskog sporazuma došlo do povlačenja tužbe ili do odricanja od tužbenog zahtjeva, ako tim sporazumom ne bi bilo ništa drugo ugovoreno, trebalo bi također uzeti da su se stranke suglasile da će svaka od njih snositi svoje do tada nastale parnične troškove, uključujući i one vezane uz navedene radnje. Do ovog bi se rješenja došlo uzimanjem u obzir pravnopolitičkih zasada na kojima su utemeljene odredba članka 158. stavka $2 .{ }^{73}$ i odredba članka 159. stavka l. ZPP-a. Ono bi zapravo polazilo od stajališta da bi u slučaju u kojemu bi spor bio riješen izvansudskom nagodbom, kojom bi bilo predviđeno povlačenje tužbe ili odricanje od tužbenog zahtjeva u parnici u vezi s kojom je ona sklopljena, a u kojoj ne bi ništa drugo bilo utanačeno u vezi s troškovima postupka, niti jedna od stranaka nije dala povod za parnicu zbog čega bi svaka od njih trebala snositi svoje troškove.

Troškovi postupka koji bi nastali zato što stranke ne bi postupile u skladu s postignutim izvansudskim sporazumom, zbog čega bi se postupak morao nastaviti, ne bi bili obuhvaćeni takvim sporazumom - za njihovu bi naknadu vrijedila opća pravila. ${ }^{74}$

72 Sud bi prigodom donošenja odluke o zahtjevima za naknadu troškova koje bi stranke istaknule unatoč drukčijim dispozicijama o tome u izvansudskom sporazumu trebao osnovanost tih zahtjeva prosuđivati u skladu s tim dispozicijama. To znači da bi sud u povodu izvansudskog sporazuma o rješenju spora koji bi sadržavao izričite ili implicirane dispozicije o troškovima postupka bio dužan, za razliku od slučaja u kojemu bi to pitanje bilo (izrijekom ili presumirano) riješeno sudskom nagodbom (vidi supra ad II.1. i 2.), donijeti posebnu odluku o tome.

73 Prema odredbi članka 158. stavka 2. iznimno od pravila da je tužitelj koji povuče tužbu ili se odrekne tužbenog zahtjeva dužan tuženiku naknaditi troškove postupka (158/1.), ako je tuženik povukao tužbu ili se odrekao tužbenog zahtjeva odmah nakon što je tuženik udovoljio zahtjevu tužitelja ili iz drugih razloga koji se mogu pripisati tuženiku, troškove postupka dužan je tužitelju naknaditi tuženik.

74 Bydlinski, op. cit. u bilj. 20, str. 699, s aspekta austrijskog prava ističe da bi u slučaju u kojemu bi stranke izvansudskim sporazumom o glavnoj stvari (izrijekom) ostavile otvorenim pitanje troškova, o tom pitanju trebalo - u pravilu ograničenjem tužbe na naknadu troškova - odlučiti primjenom procesnog prava o naknadi troškova. Odgovarajućoj bi preinaci tužbe trebalo pristupiti i kad bi se tuženik izvansudskom nagodbom obvezao naknaditi već nastale procesne troškove, ali tu obvezu ne bi ispunio; o troškovima nastalim tijekom daljnjeg postupka trebalo bi odlučiti prema $\S \S 41$. i slj. öZPO-a, dakle po općim pravilima o naknadi troškova postupka. 
U slučaju potrebe, u parničnom bi postupku (potpunim ili djelomičnim) povlačenjem tužbe, eventualno njezinim svođenjem na zahtjev za naknadu troškova postupka, odnosno preinakom tužbe ili podnošenjem protutužbe, bilo moguće primjeriti ono što se u njemu traži sadržaju postignutog izvansudskog sporazuma, ali i naknadnom ponašanju stranaka koje bi bilo protivno takvom sporazumu. $^{75}$

U slučaju povlačenja tužbe $u$ povodu postignutog izvansudskog sporazuma stranke bi mogle iznova tražiti sudsku zaštitu radi ostvarivanja svojih prava u skladu s tim sporazumom - zato što se povučena tužba smatra kao da nije ni bila podnesena i može se ponovno podnijeti (193/9.).

\section{Izvansudski sporazum i sudska nagodba zaključena na temelju tog sporazuma}

Ako bi se stranke izvansudskim sporazumom obvezale da će u postupku pred sudom (u skladu s tim sporazumom) sklopiti sudsku nagodbu i ako bi sklopile takvu nagodbu, ona bi nadomjestila taj sporazum u mjeri u kojoj bi njome bilo obuhvaćeno ono što bi bilo riješeno izvansudskim sporazumom. To bi vrijedilo i za pitanje naknade troškova postupka. Pritom bi o odnosu sadržaja sudske nagodbe i izvansudskog sporazuma ovisilo bi li in concreto bilo mjesta primjeni odredbe članka 159. ZPP-a po kojoj bi svaka stranka snosila svoje troškove koji bi nastali do zaključenja sudske nagodbe ako njome ne bi bilo drukčije ugovoreno.

\section{Odgovarajuća primjena pravila o troškovima postupka okončanog sudskom nagodbom na troškove izvansudskog rješenja spora}

Među odredbama članka 150. do 159. ZOO-a nema, kako je to već supra ad IV.1. rečeno, odredbe koja bi korespondirala onoj iz članka 159. stavka 1. ZPP-a prema kojoj svaka stranka snosi svoje troškove ako je parnica završena sudskom nagodbom, a u nagodbi nije drukčije ugovoreno. Upravo se zbog toga može postaviti pitanje potrebe i mogućnosti odgovarajuće primjene navedene odredbe ZPP-a i u slučaju izvansudske nagodbe, osobito one kojom je riješen spor koji bi se inače, da takva nagodba nije sklopljena, rješavao u postupku pred sudom.

U austrijskoj doktrini zauzeto je stajalište da odredbu $\S 47$. stavka 1. öZ$\mathrm{PO}-\mathrm{a}^{76}$ treba na odgovarajući način primijeniti i na izvansudsko rješenje nekog

75 Vidi prethodnu bilješku.

76 Vidi bilj. 9. 
pravnog spora, što bi, uz ostalo, značilo da bi se smatralo da su troškovi nastali $\mathrm{u}$ vezi sa sklapanjem takvog sporazuma međusobno prebijeni - ako sudionici u sporu glede tih troškova ne bi nešto drugo izrijekom utanačili ili se iz tog sporazuma ne bi moglo izvesti da eventualni zahtjevi za naknadu troškova nisu njime obuhvaćeni. ${ }^{77}$

Nema razloga zbog kojih se i s aspekta hrvatskog prava, arg. a cohaerentia, a completudine, per analogiam ex 159. ZPP-a, ne bi prihvatilo stajalište po kojemu bi pravila koja vrijede za snošenje i naknadu troškova postupka okončanog sudskom nagodbom bilo moguće na odgovarajući način primijeniti i na izvansudsku nagodbu. Tome bi u prilog govorila i okolnost da se prema stajalištu sudske prakse sudska nagodba zapravo tretira kao poseban formalni građanskopravni ugovor, koji se upravo zbog toga i može pobijati iz razloga zbog kojih se mogu pobijati građanskopravni ugovori, ali i na način na koji se oni mogu pobijati - tužbom. ${ }^{78}$

\section{TROŠKOVI UMJEŠAČA U SLUČAJU SUDSKE NAGODBE}

Zakonom nije izrijekom riješen troškovni status umješača u slučaju u kojemu je spor okončan sudskom nagodbom. Jedine odredbe koja se općenito tiču tog njegova statusa odnose se na pravo umješača na naknadu troškova u slučaju u kojemu je parnica okončana sudskom odlukom $\left(154 / 1.1 .{ }^{79}, 154 / 5 .{ }^{80}\right)^{81}$, odnosno na njegovu dužnost da drugim sudionicima u postupku, u prvom redu strankama, naknadi troškove postupka (154/1.2.). Upravo se zato čini opravdanim zauzeti stajalište da bi u slučaju u kojem bi spor bio okončan sudskom nagodbom pravo umješača na naknadu troškova postupka trebalo u načelu prosuđivati prema odredbi po kojoj u tom slučaju svaka stranka snosi svoje troškove, osim ako u nagodbi ne bi bilo drukčije ugovoreno (159/1.). To znači da bi umješač u načelu imao pravo na naknadu troškova postupka samo u skladu sa sklopljenom

77 Usporedi Bydlinski, op. cit. u bilj. 20, str. 698.

78 Usporedi Dika, op. cit. u bilj. 1, §§ 101., 115., 116.

79 Prema odredbama članka 154. stavka 1. ZPP-a stranka koja u cijelosti izgubi parnicu dužna je protivnoj stranci i njezinu umješaču naknaditi troškove izazvane vođenjem postupka (reč. 1.), dok je umješač na strani stranke koja je izgubila parnicu dužan naknaditi troškove koje je uzrokovao svojim radnjama (reč. 2.).

80 Odredba članka 154. stavka 5. glasi: "Sud može odlučiti da jedna stranka nadoknadi sve troškove koje su protivna stranka i njezin umješač imali ako protivna stranka nije uspjela samo u razmjerno neznatnom dijelu svojeg zahtjeva, a zbog tog dijela nisu nastali posebni troškovi."

81 Riječ je o odredbama iz kojih bi se moglo izvesti da bi njegovo pravo na naknadu troškova od protivne stranke ovisilo o uspjehu stranke kojoj se pridružio u parnici. 
sudskom nagodbom. Njegovo položaj u parnici ne bi smio biti bolji od položaja stranke kojoj se pridružio. Takvom bi rješenju odgovarala i logika nagodbe. Stranke njezinim sklapanjem nastoje cjelovito riješiti spor uključujući i troškove koji su u povodu njega nastali. Njome protivnik koji je na nju pristao hoće cjelovito riješiti i pitanje svoje obveze na naknadu troškova postupka i treba imati pouzdanja u to da je njezinim zaključenjem i to pitanje cjelovito riješeno. ${ }^{82}$

Ipak, budući da je položaj običnog umješača u određenom smislu samostalan u parnici utoliko što on uključivanjem u nju ostvaruje svoj poseban pravni interes, zbog čega stranke ne mogu spriječiti njegovu intervenciju ako su za to ispunjene zakonom predviđene pretpostavke (206.), načelni stav da umješač ne bi imao pravo tražiti naknadu troškova postupka mimo onoga što je utanačeno u sudskoj nagodbi ne bi trebalo prihvatiti u slučajevima u kojemu bi određeni troškovi bili umješaču prouzročeni krivnjom ili slučajem koji se dogodio kojoj od stranaka (arg. ex 156/1., vidi supra ad 2.7.). Pravo umješača da traži naknadu tih troškova ne bi smjelo ovisiti o konačnom rješenju spora sudskom nagodbom - bila bi riječ o troškovima pravo na naknadu kojih bi se odvojeno rješavalo od prava na naknadu troškova ovisno o ishodu spora o glavnoj stvari. Stranke bi nagodbom mogle riješiti pitanje naknade takvih svojih troškova, ali ne bi smjele moći svojim sporazumom prejudicirati samostalno pravo umješača na traži njihovu naknadu od obiju stranaka. ${ }^{83}$

82 Prema austrijskoj sudskoj praksi umješač ne može tražiti naknadu svojih troškova ako je stranka svoje troškove riješila sudskom nagodbom. Isto tako umješač nema nikakvih mogućnosti ostvarivati zahtjeve za naknadu troškova kada je stranka tijekom žalbenog postupka sklopila izvansudsku nagodbu koja je dovela do mirovanja postupka ili do povlačenja pravnog sredstva. Takav je stav judikature ocijenjen prestrogim jer je zacijelo umješačevo pravo na naknadu - materijalno opravdanim vođenjem parnice od strane glavne stranke - već nastalo, čije se ostvarenje njemu uskraćuje. Konstatira se, međutim, da u takvim slučajevima u pravilu ne predleži dostatna osnova za presuđenje mogućih zahtjeva za naknadu troškova umješača osobito zato što sadržaj nagodbe ni u kojem slučaju ne mora čak ni približno činjenično odgovarati materijalnom pravnom položaju i sadržaj nagodbe može značajno odstupati od predmeta spora jer može sadržavati sporazum o budućim poslovnim odnosima ili o nekoj protučinidbi itd. Protivno stajalište da umješaču pripada samostojan zahtjev za naknadu troškova koji bi i kod (sudske i izvansudske) nagodbe glavnih stranaka bio ostvarljiv, čini se prema ovom autoru pravnopolitički opravdanim osobito stoga što bi ono kod propuštanja pristupanja često sprečavalo negativne pravne posljedice. Primjećuje se, međutim, da öZPO za to ne predviđa nikakve instrumente. Usporedi Bydlinski, op. cit. u bilj. 20, str. 631.

83 U austrijskoj je doktrini izneseno mišljenje da bi u slučaju u kojemu bi, iznimno, glavna stranka zloupotrebom prava spriječila umješača u ostvarivanju njegova prava na naknadu troškova, njemu ona odgovarala prema općem građanskom pravu za 
Ako bi običan umješač sudjelovao kao stranka u sklapanju nagodbe, među ostalim i tako što bi je odobrio i potpisao, takva bi nagodba eventualno mogla djelovati i prema njemu kao prema stranci. Ako bi joj pristupio kao umješač, ona bi prema njemu mogla proizvoditi intervencijski učinak. Ako bi bila riječ o umješaču s položajem jedinstvenog suparničara, njegov bi pristanak na nagodbu (uključivanje u nagodbu) bio nužan za okončanje spora - ako bi se nagodbom rješavao predmet spora u postupku u kojemu bi on sudjelovao u tom svojstvu.

\section{GUBITAK PRAVA NA NAKNADU DALJNJIH TROŠKOVA PRVOSTUPANJSKOG POSTUPKA ZBOG NEPOSTUPANJA PO UPUTI SUDA ZA POKRETANJE POSTUPKA MIRENJA}

Odredbama članka 186.d ZPP-a uređen je postupak upućivanja stranaka - u povodu njihove prethodne inicijative ili neovisno o takvoj inicijativi - na postupak mirenja, koji može imati i značenje postupka u kojemu one mogu nagodbom pred sudom urediti sporni odnos u vezi s kojim je pokrenut parnični postupak, dakle, na postupak koji može imati i značenje specifičnog izvanparničnog postupka radi pokušaja sklapanja sudske nagodbe. Tim je odredbama uređena i jedna specifična troškovna sankcija koja pogađa stranku koja se aktivno ne uključi u taj postupak.

Prema odredbi članka 186.d stavka 1. ZPP-a $19^{84}$ sud može, uzimajući u obzir sve okolnosti, posebno interes stranaka i trećih osoba vezanih uz stranke te trajnost njihovih odnosa i upućenost jednih na druge, na ročištu ili izvan ročišta rješenjem uputiti stranke da $\mathrm{u}$ roku od osam dana pokrenu postupak mirenja ili rješenjem strankama predložiti rješavanje spora u postupku mirenja. Sud, dakle, po novome, može ne samo predložiti strankama da svoj spor riješe mirnim putem, kako je to bilo jedino moguće prema uređenju prije Novele

naknadu imovinske štete nastale zbog gubitka, toga prava, osobito ako se o možebitnim zahtjevima za naknadu između nje i umješača koji bi joj se pridružio ne ni odlučilo u odluci o troškovima. Ako, ipak, što bi redovito bio slučaj, ne bi predleŽalo namjerno oštećenje umješača, jer bi trebalo uzeti da bi dopušteno ostvarivanje vlastitih interesa postojalo već tada kada bi nagodba za glavnu stranku ispala povoljnijom zato što protivnik ne bi morao voditi računa o umješačevoj tražbini za naknadu troškova, umješač bi svoje troškove postupka zbog njegove ograničene procesne pozicije morao sam snositi. Zato se naglašava da bi već prije uključivanja u parnicu trebalo pažljivo ispitati treba li se preuzeti ovaj troškovni rizik ili prednost dati nekom drugom načinu pomaganja glavne stranke. Usporedi Bydlinski, op cit. u bilj. 20, str. 631 i 632.

84 Ovaj je članak u cijelosti izmijenjen člankom 20. Novele 2019. 
2019 (arg. ex 186/1. ZPP 13), već ih može i “uputiti”, zapravo naložiti im da pokrenu postupak mirenja. Štoviše, po novome sud je dužan nakon primitka odgovora na tužbu uputiti stranke da u roku od osam dana pokrenu postupak mirenja - ako su obje stranke ili dionička društva ili pravne osobe kojima je većinski član Republika Hrvatska ili jedinica lokalne i područne (regionalne) samouprave (186.d/8.). ${ }^{85}$

Da navedena "uputa" suda ima značenje i svojevrsnog naloga, potvrđuje sankcija koja je predviđena za stranku koja ne postupi prema toj uputi. Naime, prema odredbi stavka 9. članka 186.d ZPP-a 19, stranka koja je upućena pokrenuti postupak mirenja, a ne pristupi sastanku radi pokušaja mirenja, gubi pravo tražiti naknadu daljnjih troškova postupka pred prvostupanjskim sudom. Navedena sankcija pogađala bi samo stranku koja ne bi pristupila sastanku radi pokušaja mirenja i to, doslovno prema Zakonu, samo zato što nije pristupila tom sastanku. ${ }^{86}$

Budući da je prema odredbama članka 186.d stavaka 1. i 8. ZPP-a 19 sud ovlašten nametnuti strankama, dakle i protiv njihove volje, pokretanje postupka mirenja i sudjelovanje na (barem jednom?) "sastanku" pred izmiriteljem, moglo bi se postaviti i pitanje ustavnosti takvog rješenja, barem s aspekta otežavanja ostvarivanja prava na sudsku zaštitu - pitanje je li ograničenje prava na sudsko ostvarivanje pravne zaštite $\left(29 / 1\right.$. URH) ${ }^{87}$ upućivanjem na obvezatnu prethodnu provedbu pokušaja mirnog rješenja spora razmjerno naravi potrebe da se to pravo ograniči u svakom pojedinom slučaju (arg. ex 16/2. URH). To se pitanje može, najprije, postaviti s aspekta načelne primjerenosti predviđene sankcije, gubitka prava na naknadu daljnjih troškova postupka, zbog povrede nametnute

85 Rješenja iz stavka 1. članka 186.d. ZPP-a 19 sud može donijeti tijekom cijeloga parničnog postupka (186.d/2.). Ako stranke suglasno predlože ili prihvate rješavanje spora u postupku mirenja pred sudom, bez odgode će se odrediti sastanak radi pokušaja mirenja na koje se pozivaju stranke, njihovi zastupnici i punomoćnici ako ih imaju (186.d/3.). Postupak mirenja pred sudom vodi izmiritelj određen s liste izmiritelja koju utvrđuje predsjednik suda (186.d/4.). Izmiritelj ne može sudjelovati u postupku mirenja u parničnom predmetu koji mu je dodijeljen (186.d/5.). Ako se postupak mirenja dovrši bez sklapanja nagodbe, izmiritelj ne smije sudjelovati u tom sporu u bilo kojem svojstvu (186.d/6.). Nagodba sklopljena u postupku mirenja provedenom u sudu pred sucem izmiriteljem smatra se sudskom nagodbom (186.d/7.). Rješenja iz stavka 1. članka 186.d ZPP-a 19 su rješenja o upravljanju postupkom (186.d/10.).

86 Budući da glede toga nema nikakvih ograničenja, sud bi mogao i opetovano upućivati stranke na obvezatno pokretanje postupka mirenja. Moglo bi se postaviti i pitanje bi li sankcija predviđena odredbom članka 186.d stavka 9. ZPP-a pogađala samo stranku koja nije pristupila prvom sastanku pred izmiriteljem ili i stranku koja ne bi pristupila možebitnim narednim sastancima koje bi on odredio.

87 Vidi bilj. 66. 
dužnosti. Ono bi se zatim moglo otvarati i u povodu pojedinih ustavnih tužbi koje bi bile podnesene protiv odluka kojima bi strankama bilo uskraćeno pravo tražiti naknadu daljnjih troškova postupka u pojedinim slučajevima, pri čemu bi ocjena Ustavnog suda o utemeljenosti pojedinih tužbi mogla ovisiti o njegovoj ocjeni jesu li okolnosti konkretnog slučaja utvrđene u odredbi stavka 1 . članka 186.d ZPP-a opravdavale obvezatno upućivanje na postupak mirenja i je li zbog toga sankcija koja bi se očitovala u gubitku prava na naknadu troškova primjerena povredi neopravdano nametnute dužnosti.

Opravdanost novouvedene mogućnosti, ali, valja uzeti kad su za to ispunjene Zakonom predviđene pretpostavke, i dužnosti suda da stranke upućuje na obvezatnu provedbu postupka mirenja mogla bi biti dovedena u pitanje i ako bi se uzelo u obzir ovlaštenje (zapravo i dužnost) raspravnog suca da već na prvom ili izvanredno zakazanom ročištu pokuša navesti stranke na sklapanje nagodbe (arg. ex 288.a/1.. 321/3.) ${ }^{88}$ (ne kontaminirajući se pritom kao izmiritelj, zbog čega bi se inače morao izuzeti - arg. ex 186.d/5. $)^{89}$, odnosno da barem ispita ima li za to ikakvih izgleda.

Nametanje strankama provedbe prethodnog postupka mirenja, čak i kad ga one apriorno odbijaju, moglo bi im nepotrebno uzrokovati dodatne troškove troškove pojavljivanja na ročištu (sastanku) pred izmiriteljem i troškove samog postupka mirenja $\mathrm{a}^{90}$, a moglo bi pridonijeti i odugovlačenju provedbe parničnog postupka, osobito ako je hitne naravi.

Odredba članka 186.d stavka 9. ZPP-a 19 mogla bi biti protumačena i u smislu da bi sankcija o kojoj je riječ pogađala ne samo stranku koja ne bi pristupila sastanku za mirenje, već i stranku koja se ne bi ozbiljnije angažirala u pronalaženju mirnog rješenja spora. Samo po sebi inzistiranje na pristupanju sastanku za mirenje bez iskazivanja spremnosti da se pokuša izvansudski prevladati spor moglo bi novouvedenoj zakonskoj konstrukciji u određenim slučajevima dati i obilježja teatra apsurda. Ta konstrukcija, naime, omogućava "praksu" da se stranke "prekomjerno" upućuju na provedbu postupka mirenja bez mogućnosti prethodne kontrole takve sudske dispozicije - rješenje o upućivanju na postupak mirenja ima značenje rješenja o sudskom upravljanju postupkom (186.d/10.)

88 Prema odredbi članka 288.a stavka 1. ZPP-a sud je dužan tijekom pripremnog ročišta upozoriti stranke o mogućnostima da spor riješe sudskom nagodbom ili u postupku mirenja i obrazložiti im te mogućnosti, dok je prema odredbi članka 321. stavka 3. ZPP-a također dužan tijekom postupka upozoriti stranke na mogućnost sudske nagodbe i pomoći im da je zaključe.

89 Vidi bilj. 85.

90 Tu bi trebalo dodati i troškove ročišta na kojemu ih je sudac uputio na postupak mirenja. 
protiv kojega žalba uopće nije dopuštena ako je doneseno tijekom pripremanja glavne rasprave $(278 / 2 \text {. })^{91}$, a ako ima značenje rješenja o rukovođenju raspravom - posebna žalba $\left(311 / 5\right.$.). ${ }^{92}$

Premda odluka o upućivanju na postupak mirenja nije uopće ili nije izravno kontrolabilna, jer protiv nje kao protiv odluke o upravljanju postupkom odnosno o rukovođenju raspravom nije uopće dopuštena odnosno nije dopuštena posebna žalba, treba uzeti da bi stranke mogle u žalbi, među ostalim, protiv rješenja o troškovima postupka, dovesti u pitanje opravdanost upućivanja na postupak mirenja in concreto i time na opravdanost gubitka prava "tražiti naknadu daljnjih troškova postupka pred sudom prvog stupnja.” (184.d/9.).

\section{ZAKLJUČNE NAPOMENE}

Jedna od konstatacija koja bi se na temelju prethodno provedene analize zakonskog uređenja naknade troškova u slučaju u kojemu su stranke spor riješile (nastojale riješiti), u cijelosti ili djelomično, sudskom nagodbom, odnosno u slučaju u kojemu su neuspješno to pokušale postići u posebnom izvanparničnom postupku, bila bi, uz pretpostavku da su rezultati te analize makar djelomično akuratni, da je to uređenje, čak i kad ih nastoji normirati, ostavilo otvorenim čitav niz vrlo ozbiljnih pitanja, zbog čega je moguće njihovo različito razumijevanje i rješavanje. Upravo se zbog toga čini izvanredno važnim da stranke prigodom definiranja sadržaja sudske - parnične ili izvanparnične - nagodbe uznastoje riješiti i ključna pitanja u vezi s naknadom troškova postupka u kojemu su je zaključile. To posebno vrijedi za slučajeve u kojima bi zaključile međunagodbu ili djelomičnu nagodbu, osobito s obzirom na problem razgraničenja troškova koji se tiču samo onog dijela predmeta spora o kojemu bi bile zaključene takve nagodbe i troškova koji bi bili “zajednički” za taj dio predmeta spora i za onaj koji tek treba naknadno riješiti. To vrijedi i u pogledu odluka koje su prije zaključenja nagodbe donesene o naknadi određenih troškova postupka, ali i u odnosu na odluke o naknadi troškova koje će biti donesene nakon toga ${ }^{93}$, a, svakako, i u vezi sa slučajevima u kojima bi stranke nagodbom zaključenom u jednom postupku nastojale riješiti i sporove o kojima bi vodile druge postupke itd.

91 Prema odredbi članka 278. stavka 2. ZPP-a protiv odluka koje donosi sud u tijeku pripremanja glavne rasprave, a koje se odnose na upravljanje postupkom, nije dopuštena žalba.

92 Odredba članka 311. stavka 5. ZPP-a glasi: "Protiv rješenja koja se odnose na rukovođenje raspravom nije dopuštena posebna žalba.”.

93 U tom smislu zapravo s aspekta austrijskog prava i Bydlinski, op. cit. u bilj. 20, str. 699. 
U svemu tome bi uloga (zadaća) suda u upozoravanju na naznačena pitanja i na pravne posljedice njihova nerješavanja te na način njihova prevladavanja bila svakako izvanredno važna. Ostvarivanjem takve monitorno-facilitacijske funkcije suda prevenirali bi se ozbiljni problemi koji bi mogli, često nepotrebno, opteretiti ne samo buduće odnose stranaka, već i izazvati niz naknadnih sudskih postupaka.

\section{LITERATURA}

\section{Knjige i članci:}

Bazala, B., Parnični troškovi po Zakonu o parničnom postupku, Jugoslavenska advokatura, br. 1, 1958.

Betetto, N.; Galič, A., u Ude, L.; Betetto, N.; Galič, A., Rijavec, V.; Wedam Lukić, D.; Zobec, J., Pravdni postopek, Zakon s komentarjem, 3. knjiga, Ljubljana, 2009.

Betteto, N., u Ude, L.; Betetto, N.; Galič, A., Rijavec, V.; Wedam Lukić, D.; Zobec, J., Pravdni postopek, Zakon s komentarjem, 2. knjiga, Ljubljana, 2006.

Bydlinski, M., u Fasching, H. W., Kommentar zu dem Zivilprozeßgesetzen, 2. Band/1. Teilband, Wien, 2002.

Dika, M., Građansko parnično pravo, Sudske odluke i sudska nagodba, IX. knjiga, Zagreb, 2013.

Fasching, H. W., Zivilprozeßrecht, Lehrbuch des österreichischen Ziviliprozeßrechts, 2. izd., Wien, 1990.

Kaladić, I., Sporna primjena odredbe članka 159. stavka I. Zakona o parničnom postupku, Pravo i porezi, br. 10, 2007., str. $18-20$.

Kodek, G. E., u Fasching, H. W., Kommentar zu den Zivilprozeßgesetzen, 3. Band, Wien, 2004.

Poznić, B., Komentar Zakona o parničnom postupku "prema tekstu Zakona iz 1976. s docnijim izmjenama i dopunama”, Beograd, 2009.

Prančić, V., O naknadi pretprocesnih troškova u parničnom postupku, Zbornik Pravnog fakulteta u Splitu, vol. 47, br. 4, 2010., str. 861 - 886.

Rechberger, W. H.; Simotta, D.-A., Zivilprozessrecht, Erkenntnisverfahren, 9. izd., Wien, 2017.

Triva, S.; Belajec, V.; Dika, M., Građansko parnično procesno pravo, Zagreb, 1986. Triva, S.; Dika, M., Građansko parnično procesno pravo, 7. izd., Zagreb, 2004. 


\section{Zakoni:}

Ovršni zakon, Narodne novine, br. 112/2012, 25/2013, 93/2014, 55/2016 - odluka USRH, 73/2017.

Ustav Republike Hrvatske, Narodne novine, br. 56/1990, 135/1997, 8/1998, 113/2000, 124/2000, 28/2001, 41/2001, 55/2001, 76/2010, 85/2010, 05/2014.

Zakon o izmjenama i dopunama Zakona o parničnom postupku, Narodne novine, br. 117/2003.

Zakon o izmjenama i dopunama Zakona o parničnom postupku, Narodne novine, br. 70/2019.

Zakon o obveznim odnosima, Narodne novine, br. 35/2004, 41/2008, 125/2011, 78/2015, 29/2018.

Zakon o parničnom postupku, Narodne novine, br. 53/1991, 91/1992, 112/1999, 88/2001, 117/2003, 88/2005, 2/2007, 84/2008, 96/2008, 123/2008, 57/2011, 148/2011 - pročišćeni tekst, 25/2013, 89/2014 - Odluka Ustavnog suda Republike Hrvatske, 70/2019.

Zakon o parničnom postupku, Službeni list FNRJ, br. 4/1957, 52/1961; Službeni list SFRJ 12/1965, 1/1971, 23/1972, 6/1974.

Zakon o sudskom postupku u građanskim parnicama (Građanski parnični postupnik) iz 1929. 


\section{Summary}

\section{Mihajlo Dika*}

\section{COST REIMBURSEMENT IN DISPUTES RESOLVED BY A COURT SETTLEMENT}

The provision of the Croatian Code of Civil Procedure (CCP) stipulating that, unless otherwise agreed, each party in disputes resolved by a court bears its own costs (Article 159, paragraph 1 of the CCP), was not affected by the 2019 amendments to the CCP. The same is true for Article 324, which provides that the costs of the parties who attempted but failed to reach a so-called non-contentious (praetorian, preventive) settlement constitute litigation costs (Article 159 (2) CCP). Likewise, Article 324 (3), stipulating that the costs of a non-contentious settlement are borne by the initiating party, also remained unchanged. The 2019 amendments did, however, indirectly change cost-related provisions in court settlements by permitting the penalization of the party refusing the court's invitation to take part in a mediation procedure, which may also lead to a court settlement (Article 186d). The paper takes a comparative diachronic approach to the matter of costs in court settlements, focusing on court settlements reached in the course of litigation. In addition, the issue of costs in non-contentious court settlements is also dealt with, including out-of-court settlements concerning the matter in dispute, the costs of interveners in court settlements, and the loss of the right to claim further costs of a first-instance procedure for refusing to take part in mediation. Finally, the author concludes that the latest provisions fail to comprehensively regulate the above issues, leaving many questions unanswered, which could cause discrepancies in the interpretation and application of the pertinent provisions. For this reason, the author believes it is crucial for parties reaching a settlement to agree on the manner of resolving costs-related issues, be it reached in the course of litigation or in a non-contentious procedure, particularly in the event of a interim or partial settlement. The author also contends that the court should act here as a facilitator and draw the parties' attention to these matters and possible consequences of failing to resolve them.

Keywords: settlement; litigation costs; civil procedure

* Mihajlo Dika, Ph. D., Professor Emeritus, Faculty of Law, University of Zagreb, Trg Republike Hrvatske 3, Zagreb; mihajlo.dika@pravo.hr;

ORCID ID: orcid.org/0000-0002-5659-3779 